University of Rhode Island

DigitalCommons@URI

Open Access Master's Theses

1980

\title{
A Study of Housing Assistance Plans in Rhode Island
}

David M. Tonnessen

University of Rhode Island

Mark F. Rinde-Thorsen

University of Rhode Island

Follow this and additional works at: https://digitalcommons.uri.edu/theses

\section{Recommended Citation}

Tonnessen, David M. and Rinde-Thorsen, Mark F., "A Study of Housing Assistance Plans in Rhode Island" (1980). Open Access Master's Theses. Paper 741.

https://digitalcommons.uri.edu/theses/741

This Thesis is brought to you for free and open access by DigitalCommons@URI. It has been accepted for inclusion in Open Access Master's Theses by an authorized administrator of DigitalCommons@URI. For more information, please contact digitalcommons-group@uri.edu. 


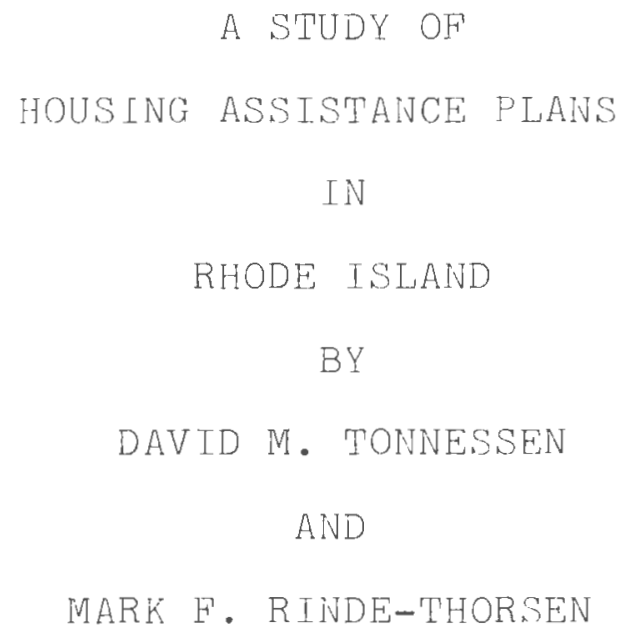

A THESIS PROJECT SUBMITTED IN PARTIAL FULFILLMENT

$$
\text { OF THE }
$$

REQUIREMENTS FOR THE DEGREE

$\mathrm{OF}$

MASTER OF COMMUNITY PLANNING

\author{
UNIVERSITY OF RHODE ISLAND \\ 1980
}




\section{MASTER OF COMMUNITY PLANNING}

\section{THESIS PROJECT}

OF

\section{DAVID M. TONNESSEN}

AND

MARK F. RINDE-THORSEN

Approved:

Thesis Project

Major Professor

and
Acting Director

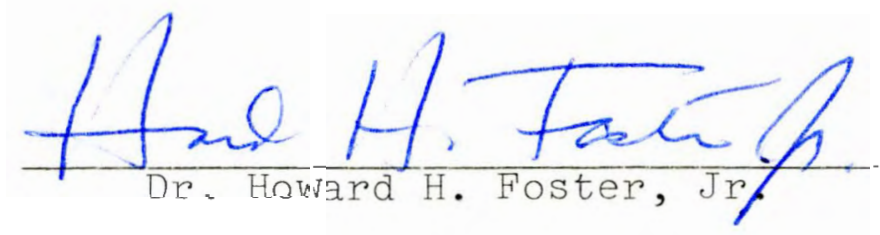


CHAPTER ONE

Page

Introduction . . . . . . . . . . . . 3

Housing Policy Issues . . . . . . . . . . 6

Additional Issues . . . . . . . . . . . . . 7

Goals.................. . 9

CHAPTER TWO

The Quagmire . . . . . . . . . . 13

The Late 1960's. . . . . . . . . . . 17

Drawing the Lines . . . . . . . . . . 21

The Housing and Community Development

Act of 1974 . . . . . . . . . . 28

Housing Assistance Plans . . . . . . . 40

The Housing and Community Development

Act of 1977 . . . . . . . . . . . . 51

The Housing and Community Development

Amendments of 1978 . . . . . . . . 55

CHAPTER THREE

Housing Assistance Plans in Rhode Island. 59

Me thodology . . . . . . . . . . . . 65

Needs................ . . 66

Goals . . . . . . . . . . . 79

Performance . . . . . . . . . . . . 87

Summary . . . . . . . . . . . . 35

CHAPTER FOUR

Recommendations and Conclusions .... 100

BIBLOGRAPHY . . . . . . . . . . . . . . 1.3 


\section{LIST OF TABLES}

Table I Rhode Island Communities with

Page

Housing Assistance Plans . . . . . . . .

Table I HAP Statements of Need and Other Measures or Indicators

(a) Metropolitan Core Narket Area . . . 72

(b) Northern R.I. ilarket Area . . . . 73

(c) Western R.I. Market Area . . . . . 74

(d) West Bay Market Area . . . . . . 75

(e) East Bay Market Area . . . . . . . 76

(f) Southern R.I. Market Area . . . . . 77

(g) Rhode Island Market Areas . . . . . 78

Table II HAP Goals for "Deep Subsidy"

Housing Assistance

(a) Metropolitan Core Market Area . . . 80

(b) Northern R.T. Ilarket Area . . . . . 81

(c) Western R. . Market Area . . . . . 82

(d) West Bay Market Area . . . . . . 83

(e) East Bay ilarket Area . . . . . . 84

(f) Southern R. I. Market Area . . . . . 85

(g) Rhode Island Market Areas . . . . . 86

Table IV HAP Need, Coals, and Assistance

Provided, 1975-1979

(a) Metropolitan Core Market Area . . . 89

(b) Northern R.I. Market Area . . . . . 90

(c) Western R.I. Market Area . . . . . 91

(d) West Bay Market Area . . . . . . 92

(e) East Bay Market Area . . . . . . 93

(f) Southern R.I. Market Area... . . . 94

(g) Rhode Island Market Areas . . . . . 95 


\section{LIST OF CHARTS}

Chart I A Comparative Analysis of Major

Page

Fending Legislation . . . . . . . . .

Chart II A Comparison of Housing Block

Grant Provisions in Pending,

Legislation . . . . . . . . . . . 33 


\section{ACKNOWLEDGEMENTS}

We wish to acknowledge our gratitude to the faculty of the Graduate Curriculum in Community Planning and Area Development of the University of Rhode Island for their efforts to guide us to this threshold.

We would especially like to thank the Denartment's Acting Director, Dr. Howard H. Foster, Jr., who, on numerous occasions, provided us with valued insipht to process and the profession which we are about to enter; and, Dr. Dennis Muniak, who's manner nrovided an opportunity for the unrestricted exchange of ideas - a quality essential to the olanning and oducational professions, yet found with increasing rarity.

Finally, we wish to take this long awaited ooportunity to express our appreciation to our fellow students, for without their varied talents this would surely have been a significantly less fruitful and enjoyable experience. 
"The principal resistance to the abolition of "housing" as a social function is certain to come from the entrenched bureaucracies that have sprung up around the concept. Those housing bureaucracies, like all other bureaucracies, are grotesquely incompetent. In the United states, which specializes in bureaucracy, housing projects built by local, state, or federal agencies invariably cost a great deal more to construct than identical housing units built by private entrepeneurs. A typical "tax dollar" dispatched by a New Yorker, for example, in the general direction of Washington, D.C., will first be collected, analyzed, crosschecked, indexed, etc., etc., by the tax collecting bureaucracy; next it will be researched, computerized, andallocated by the budgeting bureaucracy; and finally, it will be brainstormed, breakthroughed, back-fed, cross fertilized, and otherwise detumesced (and, of course statisticized) before it is returned to the public housing authority whence it came, there to be translated into buildings.

In the course of this scenic round trip, a funny thing is likely to have happened to that origional "tax dollar": it may have shrunk to something close to a nickel! Indeed, there are some who claim that truly inspired bureaucracies ucrasionally manage to shrink "tax dollars" into "minus money" by the time they try to return the cash to its proper owner (the taxpayer) or the owner's nextdoor neighbors. When "minus money" is thus generated, the bureaucracies state that their worthwhile programs are dying on the vine because they have been criminally shortchanged or underfed - and so new taxes are levied in order to realize the dreams that bureaucracy succeeded in squandering."

Peter Blake

Form Follows Fiasco 1974 
CHAPTER I 
INTRODUCTION

If there is a more optimistic view of the potential for government involvement in housing, than that of Peter Blake, it is likely to come from planners, to involve plans and planning. It is hoped that bureaucracy will not entirely dominate the process. Perhaps changes in legislation, procedures, and plans will result in better housing policy and, thereby, homes for those in need. This project seeks such changes and improvement with Rhode Island as a workshop setting and the Housing Assistance Plan (HAP) as a potential tool.

Planning exercises and efforts to describe them often begin with goals - their identification, their context and their priority. It seems appropriate in a project such as that which follows to address the planning process and our effort to utilize it. 
This study is an exploration of theoretical and practical aspects of housing and housing planning on several levels. It has the difficult goal of simultaneously engagine in the analysis and the development of policies, programs and practices. This is difficult because it involves a personal development and learning process and experience as well as more detached scholarly and intellectual interest and evaluation. It is believed that this difficulty is at the center of all planning practice. The normative and contextural predisposition of the researcher, analyst or planner inevitably affects and often effects the plans, policies, programs and practices which emerge, often with an unrealistic if not altogether unhealthy appearance or aura of that mythical source of legitimacy - "OBJECTIVITY".

Many theses and dissertations have been and will be written about the possibility or lack of possibility of objectivity. We take the position that such discussion may be useful and interesting but it lacks the potential for cloture or resolution. We therefore find it both necessary and sufficient to express a recognition of the problem and to deal with it through some articulation of predisposition and pre-existing philosophy which, no doubt, colors all that follows. The utility of our results or recommendations, therefore, depends upon the predisposition and orientation of the reader as much as 
any other fiactor.

Having identified the problem of attempting to simultaneously influence, study, evaluate and improve housing policy, it is appropriate to outline at least some part of the philosophic and value judgements that derive from previous as well as current study and experience. It is hoped that this expression will help to explain what follows, where values always inhere but may be less distinguishable. We do not believe the utility of our analysis to be entirely dependent upon adoption or acceptance of this orientation, but rather that this introduction is a more honest way to approach the subject and provide a context in which to evaluate our ideas as they develop.

Housing is a field of interest in which it is perhaps most appropriate for planners to operate. It consists of both psychological and physical dimensions; it is a social good or commodity as well as a material structure. Any conscious government of private action to deal with housing necessarily involves values and aesthetics, physics and economics, sociology and engineering. Government action and activity in the field must deal with these and other concerns. A variety of policy issues emerged during the period studied which affected our analysis and efforts to bridge the considerable 
intellectual distance from noble phrases like "A Decent Home..." for all Americans to the "Nuts and Bolts" of a Housing Assistance Plan.

Housing Policy Issues

I. There is a lack of national policy in the area of housing. There are many programs of course, but they do not and cannot add up to a coordinated commitment to identification and solution of the problems faced in the field. The inevitable relationship of housing to wider social welfare concerns, including employment and income transfer issues, seems ignored or even in contention with many housing programs.

II. Conflicting goals complicate housing programs and efforts to establish policy. The provision of housing as a social good is not and cannot be the same as support of the construction industry and manipulation of the economy. Perhaps these goals can be reconciled and even addressed at the same time, but they are not the same; the relative priority of goals needs clarification if and when policy is made and implemented.

III. The implementation of housing programs in the United States is, for the most part, through the U.S. Department of Housing and Urban Development (HUD). Yet, 
housing expert Chester Hartman and others have observed, "the largest subsidy given to housing comes through the workings of the Internal Revenue Code..." and public welfare programs "provide more direct subsidization for housing low-income families than all other government housing programs combined." ${ }^{l}$ Until these and other disparate and independent agencies and programs are coordinated in some way, housing policy in this country will continue to remain elusive if not impossible.

Aditional Issues

Federalism is a key feature of the American political system. The "New" federalism of the Nixon Administration, however, was less long term, agreed upon philosophic commitment than a temporary expression of one administration's perceived "mandate", one effort to address the ever changing balance of commitment and control of policy and programs among different levels of government. The current administration has continued some programs and concepts of its predecessors. This implies but does not guarantee continued faith in local input and control.

No one level of government has a monopoly on expertise, ability, authority or competence in the administration of housing programs. We are personally predisposed, 
however, toward "higher" levels of government when dealing with broad issues such as housing. The need for national action and control is seen very nearly analagous to national defense and is certainly related to the overall health and welfare of the country.

This perception does not mean that all planning and implementation must be on the national level. Individual municipalities, however, are seen as frequently unwilling or unable to effectively address issues of such broad concern and importance, in terms of both vision or spheres of influence and levels of expertise. Personal experience with local governments has been, for the most part, depressing. Municipalities, especially in New England where there seems to exist a perverse pride in a history of noncooperation, cannot be depended upon to provide for equality of economic and housing opportunity. Such opportunities must transcend the political boundaries of individual cities and towns.

Regional and metropolitian planning, however geographically defined, are seen as experiments with limited success. Not the least of the problems are related to identy, conflicting political boundaries and jurisdictions. The state, therefore, and particularly one with the manageable size and population of Rhode Island, is 
seen as a viable alternative to a new or additional organizational locus for planning. Perhaps this state may prove willing and able to provide the initiative and incentive to effect some coordination of public programs .

Bureaucracies at all levels of government - local, state, or federal - not only effect public policy but also affect such policy needs and with goals of their own, most notably self-perpetuation. The "carrot and stick" aporoach of the Federal Government is for from neutrally administered by the Executive branch and its Departments. The values of countless participants are involved if not imposed in the execution and implementation of policy and programs. In large measure because of our concern for bureaucratic and institutional requirements, we have selected one such feature - the Housing Assistance Plan - for analysis.

Comprehensiveness, that elusive if not unattainable goal, seems more a state of mind than the subject of organization, law or regulation. It is a way of looking at things made difficult by societal specialization and our political system and structure. Rather than attempt to devise a mechanism to achieve it in a yet to be realized ideal world, this study begins with a real world 
feature, some paperwork called a HAP, the acronym for Housing Assistance Plans unfortunately shared with closely related Housing Assistance Payments, Housing Allowance Programs, and Housing Allocation Plans. It, or some similar document, is likely to remain a feature of the planning and provision of housing in this country; it is felt that it may prove to be a vehicle for the improvement of these processes.

Goals

Our goals, reflected in the chapters which follow, are to:

I. Understand housing and HAP's in the political and legislative history of the twentieth century United States.

II. Describe and analyze Rhode Island HAP's within this and our own philosophic and theoretical perspective and orientation.

III. Acquire practical skills related to the preparaation, analysis and implementation of Hap's through the development of recommendations for improvement. 
Footnotes

1. Chester W. Hartman, Housing and Social Policy (Englewood Cliff's, N.J.: Prentice Hall, 1975). 
CHAPTER II 
The Quagmire

It is the intent of this chapter to review the legislative and political background of that component of the Community Development Act of 1974 known as the Housing Assistance Plan and to indicate the impact which it has had in the development of realistic, comprehensive, and humanitarian housing programs for low- and middle-income families.

The most crucial aspect of this evaluation lies in the ability to maintain a holistic perspective of the activities which surrounded the formulation and passage of the 1974 Act. It is with consistent regularity that attempts are made to relate only a small portion of a story, to analyze something apart from the atmosphere in which it was created and without consideration of the constraints to which it was compelled to adapt. It is therefore with equal regularity that we are led to con- 
fusion and inaccuracy in the formulation of conclusions, strategies, programs and policies.

In retrospect, one might wonder whether it was at all reasonable to expect a viable program to emerge from an administration and a Congress, entrenched in a quagmire of national and international crises, the complexity of which we can only now begin to fully appreciate - Vietnam, Watergate, Civil Disorder, The Middle East, OPEC, inflation, and so on.

Although various fundamental objectives may be conceived and progress to achieve some degree of longevity in the halls of Congress, or among the members of the numerous executive departments, specific programs do not. The advent of a new administration or another session of Congress signals the opening of another season on all manner of programs and policies, and few have been known to survive intact for the duration of yet one administration. No policy or program, whether in the field of housing, community develonment, or elsewhere can expect to achieve more than a temporary predominance in the evolutionary process of democratic legislation as it exists in this country.

This condition has been well documented in the field 
of housing. Although our overall national housing policies may change less frequently legislative history reflects the passage of a new series of housing programs approximately every one and one-third vears since the forerunner in the field was presented in 1934. These Acts have included:

1934 - The National Housing Act of 1934

1937 - The United States Housing Act of 1937

1939 - The Housing Deficiency Act

1940 - The Defense Housing Appropriations Act

1942 - The Defense Housing Act of 1942

1945 - The General Housing Act

1947 - The Housing and Redevelooment Act of 1947

1948 - The Housing and Redevelopinent Act of 1948

1948 - The Housing Act of 1948

1949 - The Housing and Redevelooment Act of 1949

1949 - The Housing Act of 1949

1950 - The Housing and Redevelonment Act of 1950

1950 - The Housing Act of 1950

1951 - The Defense Housing and Community Facilities and Services Act of 1951

1952 - The Housing Act of 1952

1953 - Housing Amendments of 1953

1953 - The National Housing Act of 1953

1953 - The Housing and Redevelopment Act of 1953

1954 - The Housing Act of 1954 
1955 - Housing Amendments of 1955

1956 - The Housing Act of 1956

1957 - The Housing Act of 1957

1959 - The Housing Act of 1959

1961 - The Housing Act of 1961

1964 - The Housing Act of 1964

1965 - The Housing and Urban Develonment Act of 1965

1966 - The Demonstration Cities and Metropolitian Development Act of 1966

1968 - The Housing and Urban Development Act of 1968

1968 - The Civil Rights Act of 1968

1969 - The Housing and Urban Development Act of 1969

1970 - The Housing and Urban Development Act of 1970

1974 - The Housing and Community Development Act of 1974

1976 - The Housing Authorizations Act of 1976

1977 - The Housing and Community Development Act of 1977

1978 - The Housing and Community Development Amendments of 1978

Despite the considerable dimensions of this family tree, it become necessary to return only to that generation of housing legislation which immediately preceded the 1974 Housing and Community Development Act in order to identify the specific hazards which any policy or program is likely to confront. 
The Late $1960^{\prime} \mathrm{s}$

The Housing and Urban Development Act of 1968 was one of the final pieces of legislation which the administration of President Lyndon B. Johnson was able to maneuver through Congress in his attempt to build the "Great Society", and it represented a substantial commitment to the needs of low- and moderate-income groups. In total, it had provided funding for the expansion of seven existing programs and had created twelve additional ones. Yet, between the time at which the program was adopted and that at which it was implemented, it was to undergo substantial change.

President Richard M. Nixon assumed responsibility for establishing the course of direction which the country would follow in January, 1969, and he determined that the great ship's course would differ from that which his predecessor had set. These changes have become rather traditional and many look upon them as a demonstration of the incoming administration's ability or attempt to produce programs which would succeed where others have failed. On the other hand, there are those who see only that generation after generation of potentially helpful legislation has fallen prey to the laws of "inescapable discontinuity" and "compulsive innovation", apparently 
features inherent to our political system.

However, the Johnson administration's legislation had not yet had time to fail; in fact, it had not yet had time to be implemented. Therefore, it was too young a program to be discarded or abandoned without a strong note of dissent being raised by an already angered and vocal population of expectant recipients demonstrably low on patience. It was therefore decided that the legislation would remain but that its focus would be dramatically altered in order to reflect the concerns of the new administration. The focal point of the new series of programs became known as "Operation Breakthrough" an attempt to meet the housing needs of the country by providing massive economic stimulation to the producers of pre-fabricated housing.

However, the rapid and haphazard manner in which the program was assembled foretold the future of the federal government's latest attempt to address the nation's rather deplorable housing conditions for low- and moderate-income families. The nation, led by an inexperienced administration preoccupied with numerous other commitments which had been placed upon it, would find that once again it would have to reassess the situation and devise yet another mechanism in order to move us toward that 
long awaited goal so eloquently stated in the Housing Act of 1949,"...A decent home in a suitable living environment for ever American family."

It became necessary to adopt a temporary measure for the provision of housing opportunities, and Congress and the Administration chose to rely on additional appropriations for the Section 23 "Assisted Housing Program". The Section 23 Program was a major component of the U.S. Housing and Urban Development Act of 1965 and, in effect, it allowed local Public Housing Authorities (PHA) to lease existing units, in privately owned buildings, for use by low income families.

This provision proved insufficient to meet the demand and so, in 1972, the Department of Housing and Urban Development (HUD) attempted to expand the effectiveness of the program by providing subsidized rents in newly constructed units and, thus, expanded the "leased housing" program. This revision substantially increased the interest of the construction industry, which in times of economic recession frequently relied on those programs subsidized by the federal government, and it soon became the dominant aspect of the program.

However, the effectiveness of the nrogram remained 
much in question and it appeared that battle lines were gradually being drawn around the alternative methods for providing housing assistance. The Nixon administration became increasingly disenchanted with this situation and in January, 1973, it decided to impose a moratorium on the construction of all public housing units. In addition, Nixon announced his intention to promote a program which would replace the Section 23 subsidy with one that would provide direct cash assistance to low-income families. This action resulted in the cancellation of 100,000 units of public housing scheduled for release at that time and the effects were felt immediately by a variety of groups.

The administration shortly thereafter became entangled in the controversy surrounding the "Watergate" incident and thus found it necessary to temporarilly remove itself from an active role in the establishment of a new public housing policy. The responsibility therefore abruptly shifted to Congress and HUD, and some confusion resulted. It was thought that an interim return to the Section 23 program would offer time in which to further consider the issue. Yet, it was well recognized that the procedures and funds alloted to this program were insufficient to resolve the long standing problems with which they were faced. It was at this point that a number of 
suggested revisions, prompted by the Nixon Administration's concern over the viability of the preceding programs, received new interest in Congress.

Drawing The Lines

\begin{abstract}
"l'oday we begin hearings on pending housing and community development legislation. We do so at a time of great uncertainty and frustration concerning future Federal efforts in housing and community development. The President's housing proposal recently submitted to Congress represents, in the eyes of many, a full retreat from the bipartisan national commitment to provide decent housing for our citizens. Congressional proposals, on the other hand, attempt to maintain that commitment, providing new and improved tools to serve our housing needs.

I hope that we are mistaken in our view of the administration's goal. I hope our differences involve only the most effective ways to serve housing needs and not the need to serve them at all."I
\end{abstract}

Both Congress and the Department of Housing and Urban Development continued to examine the housing situation in the months that followed, and they attempted to develop legislation which would lead to the resolution of this increasingly embarrassing predicament. However, as the leaves began to fall in late 1973, it became apparent that yet another year would pass without an agreement on a comprehensive housing strategy for the United States. In fact, an accurate description of the situation at this point might justifiably center on the term 
"dismal". The House of Representatives and the Senate each contained factions which supported three different legislative approaches to the problem:

I. House Bill HR 10036 Consolidation and Reform of Senate Bill S 2182 Existing Housing Assistance Programs

II. House Bill HR 10036 Housing Block Grant Senate Bill S 2182

III. House Bill HR 10688 Housing Cash Allowances Senate Bill S 2507

The Administration, on the other hand, was adamant in its desire to discontinue the existing housing subsidy programs, and, in the final report of the six month study it had conducted on federal housing policies, it announced a preference for those proposals which suggested a form of cash housing allowance payments. However, the Administration stopped short of endorsing a specific proposal and stated that it would delay its final decision until late 1974 or early 1975.

The Administration realized that such procrastination might lead to considerable upheaval in many circles and so, in an act of conciliation, proposed a relaxation 
of the existing moratorium on housing assistance. It also decided that an effort should be made to address the needs of moderate-income families and suggested that equal attention be paid to this issue.

While the Congress could not be said to be in anything other than marginal agreement with the Administration's position concerning the futility of the existing: housing subsidy programs, it did acknowledge the need to pacify a number of interested parties who had been awaiting action for the past three years. Such organizations as The National Association of Housing and Redevelopment Officials (NAHRO), The National Association for the Advancement of Colored People (NAACP), and a variety of State Housing Authorities appeared before the Subcommitties on Housing in both the senate and the House of Representatives and asked that funds for existing programs not be entirely severed until agreement could be reached on new legislation.

Neither the House nor the Senate could mistake the sentiments expressed by these groups; yet, they feared a Presidential veto of any resolution which appeared to divergent from the views expressed by the Administration. Therefore, without the full support of the congress and the Administration, it became impossible to offer anything 
more than another stopgap measure which, in effect, constituted a declaration of unlimited further procrastination.

This situation led the Board of Governors of the National Association of Housing and Redevelopment Officials to declare in their joint statement of April 19, 1974, that "...the national commitment to attain "a decent home in a suitable living environment for every American family", is foundering to a point of complete collapse. The record of the last three years - one of slow-downs, suspensions, terminations, and fund withholdings in federally-assisted housing and community development programs - has brought the national effort to a virtual standstill".

The NAHRO Board of Governors went on to suggest that Congress should appropriate "...full levels of federallyassisted program activities for the new fiscal year... in order to carry forward a national commitment to housing and community development needs", 3 if an agreement could not be reached as to what direction the new housing policy should follow within the immediately forseeable future. Their recommendations included provisions for: 


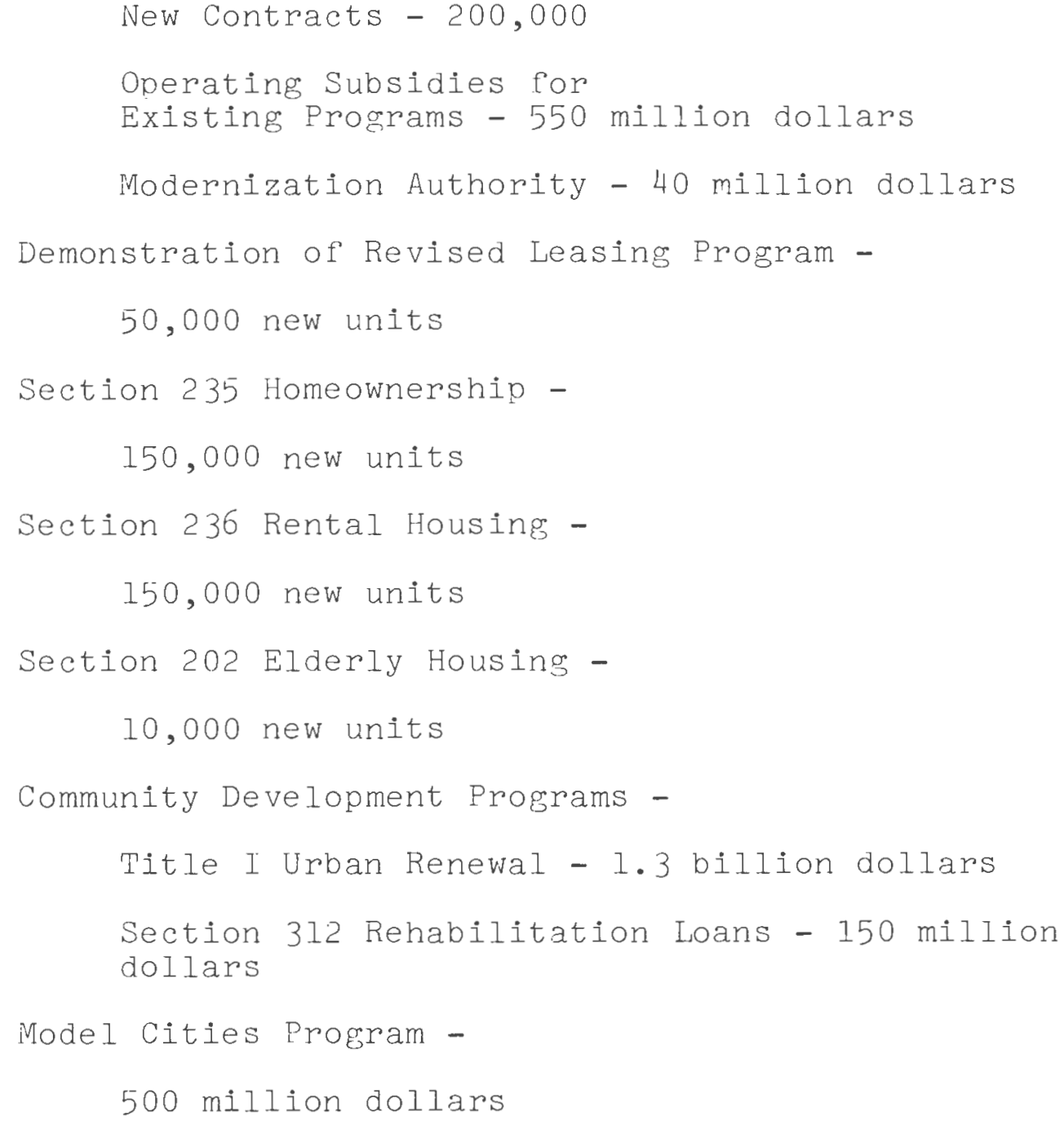

Similar provisions were suggested by other organizations; yet, it was exactly such proposals which the Administration solght to avoid. However, in consideration of the increased pressure being placed on Congress and the Administration, it became imperative that substantial progress now take place.

The Executive and Legislative bodies of the govern- 
ment had been debating the issues for more than three years and were still unable to reconcile their differences.

The Administration's overall position centered around a program which, as stated, would provide direct cash allowances to families of low-income. The plan further recommended that the existing housing programs be terminated on an incremental basis. The Section 235 and 236 programs would be eliminated immediately and the new public housing program would be discontinued after December 31, 1975. At that time they would be replaced with a program which would provide an eligible family with that dollar amount which constituted the difference between the annual fair market rent, for the area in which they lived, and twenty-five percent of their annual income. The Administration maintained that such a program would effectively stimulate the construction or rehabilitation of existing housing units throughout the local area. In addition, the program would attempt to insure the geographic dispersion so fervently sought by permitting no more than twenty percent of all dwelling units within any one development to be subsidized.

However, the Administration remained reserved in its expectation of this program's success and consistently 
called for a trial period in which only a modest commitment of resources be made. As Nixon had stated, "Too often in the past new Federal programs have been launched on a sea of taxpayers' dollars with the best intentions but with too little information about how they would work in practice".

The Senate preferred, by and large, to continue the existing housing assistance programs in their entirety with only minor reforms. The House agreed that reform was necessary among the variety of existing programs and that they should continue. However, it suggested that any new public housing be developed in relation to, and as a component of, the more broad based block grant form of subsidy.

Both the Senate and the House had spent considerable time examining the block grant approach and listening to the testimony of a great variety of individuals and organizations; yet, their oninion on the subject differed substantially. The senate favored the block grant method only as a mechanism for allocating funds for existing housing programs. The House, however, had an expanded view of the capabilities of such an approach and fought strenuously for its adoption. They envisioned a combination of existing housing and rehabilitation programs 
which provided maximum flexibility on the municipal level and avoided the categorization and funding of housing programs according to snecific title. A more specific comparison of the proposed legislation appears in: Chart I - A Comparative Analysis of Major Pending Legislation; and, Chart II - A Comparison of Housing Block Grant Provisions in Pending Legislation.

The membership of both the House and the Senate undertook a final review of the proposed alternatives but were unable to resolve the differences which existed between them. It was therefore required that both the House and Senate Bills be transferred to the Managers of the Committee of Conference who would attempt to resolve the conflict which had continued for what was approaching the four year mark.

The Housing and Community Development Act of 1974

What emerged from the Committee of Conference became, on August 22, 1974, The Housing and Community Development Act of 1974 - Public Law 93-383. The legislation would become effective on January 1, 1975, and it would most closely resemble the alternative proposed by the House of Representatives. It would institute a block grant program which combined all of the remaining HUD catagor- 


\section{REFORM OF EXISTING HOUSING ASSISTANCE PROGRAMS: COMPARATIVE ANALYSIS OF MAJOR PENDING LEGISLATION}

Prepared by NAHRO Policy and Research Division

\begin{tabular}{|c|c|c|c|c|}
\hline Issue & Existing Law & Senate Bill: S2182 & House Bill: HR10036 & $\begin{array}{c}\text { Administration Housing Bill- } \\
\text { S2507, HR10688 }\end{array}$ \\
\hline \multirow[t]{4}{*}{ New Authorization } & Section 235 (402) Homeownership & 200 million dollars on $7 / 1 / 74$ & 150 million dollars on $7 / 1 / 74$ & \\
\hline & Section 236 (502) Multi-family & 300 million dollars on $7 / 1 / 74$ & 200 million dollars on $7 / 1 / 74$ & \\
\hline & Public Housing: & 140 million dollars on $7 / 1 / 73$ & 140 million dollars on $7 / 1 / 73$ & 140 million dollars on $7 / 1 / 73$ \\
\hline & $\begin{array}{l}\text { Rent Supplement: Consolidated under } \\
\text { Section } 502 .\end{array}$ & 250 million dollars on $7 / 1 / 75$ & & $\begin{array}{l}\text { No new public housing contracts } \\
\text { after } 12 / 31 / 75 \text {. }\end{array}$ \\
\hline \multirow[t]{2}{*}{$\begin{array}{l}\text { Mortgage and } \\
\text { Consiruction } \\
\text { Cost Limits }\end{array}$} & $\begin{array}{l}\text { Section 235: Maximum mortgage } \\
\text { amount cannot exceed } \$ 18,000 \text { for a } \\
\text { single-family house, with up to } \$ 3000 \\
\text { additional in high cost areas. } \\
\text { Section 236: Maximum mortgage } \\
\text { amount for any development is } 12.5 \\
\text { million dollars; individual unit ceiling } \\
\text { based on sliding scale, three bed- } \\
\text { room, elevator unit maximum of } \\
\$ 23,000 \text { : up to } 45 \text { percent nore in } \\
\text { high cost areas. }\end{array}$ & $\begin{array}{l}\text { Sections } 402 \text { and 502: Prototype costs } \\
\text { based on estimate of construction } \\
\text { costs of new dwelling units in the } \\
\text { areas and the Secretary's estimate of } \\
\text { reasonable allowances for cost of land } \\
\text { and site improvements. Mortgage } \\
\text { amount shall not exceed prototype } \\
\text { cost by more than } 20 \text { percent. }\end{array}$ & $\begin{array}{l}\text { Same as in Senate bill for Sections } 402 \\
\text { and } 502 \text {. except that mortgage } \\
\text { amounts shall not exceed } 10 \text { percent } \\
\text { of prototype. }\end{array}$ & $\begin{array}{l}\text { Sections } 235 \text { and } 236 \text { are deleted } \\
\text { from the statute. }\end{array}$ \\
\hline & $\begin{array}{l}\text { Public Housing: Prototype construc- } \\
\text { tion costs determined by HUD in } \\
\text { each local market area at least an- } \\
\text { nually. Mlaximum construction cost } \\
\text { can be } 110 \text { percent of prototype cost, } \\
\text { excluding land, demolition, and non- } \\
\text { dwelling facilities. }\end{array}$ & Same as existing law. & $\begin{array}{l}\text { Prototype ceiling of } 110 \text { percent based } \\
\text { on total development cost, including } \\
\text { land and demolition, excluding only } \\
\text { nondwelling facilities and relocation } \\
\text { payments. }\end{array}$ & Same as HR10036. \\
\hline \multirow[t]{2}{*}{ Income Limits } & $\begin{array}{l}\text { Sections } 235 \text { and } 236 \text { : usually } 135 \\
\text { percent of public housing limits; two- } \\
\text { year recertification of income. }\end{array}$ & $\begin{array}{l}\text { Sections } 402 \text { and } 502 \text { : up to } 90 \text { per- } \\
\text { cent of the median income in the } \\
\text { atea, as determined by the Secretary. }\end{array}$ & $\begin{array}{l}\text { Sections } 402 \text { and } 502 \text { up to } 80 \text { per- } \\
\text { cent of the median income in the } \\
\text { area, as determined by the Secretary. }\end{array}$ & $\begin{array}{l}\text { Sections } 235 \text { and } 236 \text { deleted from } \\
\text { the statute. }\end{array}$ \\
\hline & $\begin{array}{l}\text { Public Housing: Families in the low- } \\
\text { est income group who cannot afford } \\
\text { to pay for unassisted private housing: } \\
20 \text { percent of admission income must } \\
\text { be at least } 80 \text { percent of rentals of } \\
\text { unassisted housing; continued occu- } \\
\text { pancy at } 125 \text { percent of admission } \\
\text { limits: income recertification for fam- } \\
\text { ilies at least annually and, for elderly, } \\
\text { every two years. }\end{array}$ & $\begin{array}{l}\text { Public Housing: Same as existing } \\
\text { law, except no percentage gap be- } \\
\text { tween income and rents in unassisted } \\
\text { private housing. } \\
\text { Low-income families means families } \\
\text { of "low income." }\end{array}$ & $\begin{array}{l}\text { Public Housing: Same as S2182, ex- } \\
\text { cept low-income families are defined } \\
\text { as famisies of "lowest" incuine. }\end{array}$ & Public Housing: Same as HR10036. \\
\hline \multirow[t]{2}{*}{$\begin{array}{l}\text { Definition of } \\
\text { Income }\end{array}$} & $\begin{array}{l}\text { Sections } 235 \text { and } 236: 95 \text { percent of } \\
\text { all gross earnings of family members } \\
\text { over } 21 \text {, with deduction of } \$ 300 \text { per } \\
\text { minor. }\end{array}$ & $\begin{array}{l}\text { Sections } 402 \text { and } 502 \text { : Same as defini- } \\
\text { tion for public housing used in com- } \\
\text { puting } 25 \text { percent rent ceiling, except } \\
\text { secondary wage earner must be the } \\
\text { spouse of the head of the household; } \\
\text { excludes income from child placement } \\
\text { care. }\end{array}$ & $\begin{array}{l}\text { Sections } 402 \text { and 502: Tenant's in- } \\
\text { come, as determined by the Secretary. }\end{array}$ & $\begin{array}{l}\text { Sections } 235 \text { and } 236 \text { deleted from the } \\
\text { statute. }\end{array}$ \\
\hline & & & & Continued on following page \\
\hline
\end{tabular}




\begin{tabular}{|c|c|c|c|c|}
\hline \multirow[t]{3}{*}{ Issue } & Existing Law & \multirow{3}{*}{$\begin{array}{l}\text { Senate Bill: S2182 } \\
\text { Public Housing: Same as for Sections } \\
402 \text { and } 502 \text { above, except } 5 \text { percent } \\
\text { ard } 10 \text { percent deductions from gross } \\
\text { income are eliminated. }\end{array}$} & \multirow{3}{*}{ 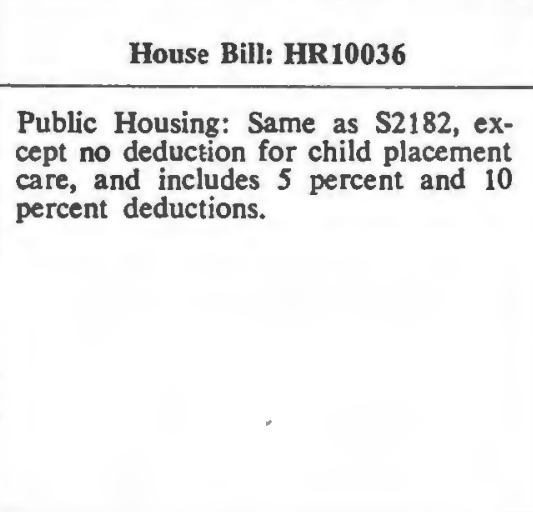 } & \multirow{3}{*}{$\begin{array}{l}\text { Administration Housing Bill- } \\
\text { S2507, HR10688 }\end{array}$} \\
\hline & $\begin{array}{l}\text { Public Housing: General: LHA } \\
\text { makes deductions for minors and for } \\
\text { certain expenses, subject to HUD ap- } \\
\text { proval. }\end{array}$ & & & \\
\hline & $\begin{array}{l}\text { For computing rent under } 25 \text { percent } \\
\text { rent ceiling: gross income of all over } \\
18 \text { years, excluding nonrecurring in- } \\
\text { come, income of fultime students, } \\
\$ 300 \text { for each dependent and second- } \\
\text { ary wage earner, } 5 \text { percent of gross } \\
\text { income, and } 10 \text { percent in case of } \\
\text { elderly, and extraordinary medical ex- } \\
\text { pense. }\end{array}$ & & & \\
\hline \multirow{2}{*}{$\begin{array}{l}\text { Rental Occupancy } \\
\text { by Income Levels } \\
\text { a. Continued } \\
\text { Occupancy } \\
\text { Limits }\end{array}$} & Sections 235 and 236: No limits. & Sections 402 and 502: No limits. & Sections 402 and 502: Same as $\$ 2182$. & $\begin{array}{l}\text { Sections } 235 \text { and } 236 \text { deleted from } \\
\text { statute. }\end{array}$ \\
\hline & $\begin{array}{l}\text { Public Housing: Requires continued } \\
\text { occupancy limits, with some exception } \\
\text { for short-term situation. }\end{array}$ & $\begin{array}{l}\text { Public Housing: Eliminates con- } \\
\text { tinued occupancy limits. }\end{array}$ & Public Housing: Same as S2182. & No limits. \\
\hline \multirow[t]{2}{*}{$\begin{array}{l}\text { b. Occupancy } \\
\text { by Lowest } \\
\text { Income }\end{array}$} & $\begin{array}{l}\text { Section 236: Rent supplements can } \\
\text { be used in conjunction with } 1 \text { percent } \\
\text { interest rates on } 20 \text { to } 40 \text { percent of } \\
\text { units. }\end{array}$ & $\begin{array}{l}\text { Section 502: With respect to } 20 \text { per- } \\
\text { cent of divelling units in any project, } \\
\text { Secretary may make additional pay- } \\
\text { ments to reduce rents on tenants' units } \\
\text { to afford basic rent within } 25 \text { percent } \\
\text { of income. } \\
\text { Not less than } 50 \text { percent of these as- } \\
\text { sisted units must be for very low- } \\
\text { income families those whose in- } \\
\text { comes do not exceed } 50 \text { percent of } \\
\text { median income for the area. }\end{array}$ & $\begin{array}{l}\text { Section 502: For nonelderly projects, } \\
\text { at least one-half of the units at initial } \\
\text { rent-up must be for those families } \\
\text { where basic rental charges do not ex- } \\
\text { ceed } 20 \text { percent of their incomes. } \\
\text { Secretary may make additional pay- } \\
\text { ments to cover families not covered } \\
\text { above but these payments cannot ex- } \\
\text { ceed an amount which would reduce } \\
\text { the aggregate fair market rental } \\
\text { charges to } 80 \text { percent (65 percent for } \\
\text { elderly) of the aggregate basic rental } \\
\text { charge. }\end{array}$ & $\begin{array}{l}\text { Sections } 235 \text { and } 236 \text { deleted from } \\
\text { statute. }\end{array}$ \\
\hline & $\begin{array}{l}\text { Public Housing: Serves lowest income } \\
\text { group. }\end{array}$ & $\begin{array}{l}\text { Public Housing: At least } 20 \text { percent } \\
\text { of occupancy in any new public hous- } \\
\text { ing project must be by very low-in- } \\
\text { come families, as defined by the } \\
\text { Secretary. }\end{array}$ & $\begin{array}{l}\text { Public Housing: Operating subsidy } \\
\text { made contingent on establishment of } \\
\text { tenant eligibility criteria which will } \\
\text { assure a broad range of incomes. }\end{array}$ & $\begin{array}{l}\text { Public Housing: No provision on } \\
\text { cross-section. }\end{array}$ \\
\hline \multirow[t]{3}{*}{ Rental Charges } & $\begin{array}{l}\text { Section 236: Rent-income ratio of } 25 \\
\text { percent but a basic rent based on a } 1 \\
\text { percent mortgage. }\end{array}$ & $\begin{array}{l}\text { Section 502: Basic rentals or such } \\
\text { greater amount as represents } 25 \text { per- } \\
\text { cent of income; minimum rent equal } \\
\text { to utilities. }\end{array}$ & $\begin{array}{l}\text { Section 502: Not less than } 20 \text { percent } \\
\text { of each tenant's income, not exceed- } \\
\text { ing fair market rent. }\end{array}$ & $\begin{array}{l}\text { Sections } 235 \text { and } 236 \text { deleted from } \\
\text { statute. }\end{array}$ \\
\hline & $\begin{array}{l}\text { Public Housing: Maximum rent-in- } \\
\text { come ratio of } 25 \text { percent, except ratios } \\
\text { vary by household size. }\end{array}$ & $\begin{array}{l}\text { Public Housing: Maximum rent-in- } \\
\text { come ratio of } 25 \text { percent but mini- } \\
\text { mum rent at } 40 \text { percent of operating } \\
\text { cost. }\end{array}$ & $\begin{array}{l}\text { Public Housing: Maximum rent-in- } \\
\text { come ratio of } 25 \text { percent but mini- } \\
\text { mum rent at } 20 \text { percent of operating } \\
\text { cost. }\end{array}$ & $\begin{array}{l}\text { Public Housing: Same as S2182, ex- } \\
\text { cept operating cost calculation, (for } \\
40 \text { percent) based on both project- } \\
\text { supplied and tenant-supplied utilities. }\end{array}$ \\
\hline & $\begin{array}{l}\text { Public Housing-Tenants receiving } \\
\text { welfare: Tenants receiving welfare as- } \\
\text { sistance pay rents on same basis as } \\
\text { other tenants; welfare agencies cannot } \\
\text { reduce benefits if LHA reduces rents. }\end{array}$ & $\begin{array}{l}\text { Tenants receiving welfare assistance } \\
\text { shall not exceed the greater of } 40 \\
\text { percent of operating cost or the max- } \\
\text { imum amount of welfare assistance } \\
\text { they are entitled to receive for hous- } \\
\text { ing. }\end{array}$ & $\begin{array}{l}\text { Tenants receiving welfare assistance } \\
\text { pay rents on the same basis as non- } \\
\text { welfare tenants. }\end{array}$ & $\begin{array}{l}\text { "The relationship between housing } \\
\text { programs and welfare programs is } \\
\text { particularly critical. We must care- } \\
\text { fully consider the ways in which our } \\
\text { housing programs will relate to olher } \\
\text { programs which also assist low-in- } \\
\text { come persons." (President's message } \\
\text { of September 19, 1973.) } \\
\text { No welfare provision in bill. }\end{array}$ \\
\hline
\end{tabular}


Public Housing: No minimum rentincome ratio requirement.

Operating Subsidy

Section 236: No provision for operating subsidy.

Public Housing: Operating subsidy available to assist local housing authorities to achieve and maintain adequate operating services and reserve funds. Allocation of operating subsidy is currently based on November 1972 HLD formula. Level for fiscal year 19 i is 280 nnillion dollars.
Public Housing: To receive operating subsidy, the aggregate rentals in a local housing authority progran mus be at least 20 percent of aggregate incornes (an average rent-income ratio of 20 percent)

Section 502: Secretary may make additional assistance paymenis after initial rent-up not in exiss of (a) the amount by which the cost of utilities mointer which mine level or (b) the anount minin basic rent levels not in cess of 30 percent of income of ex enant.

Public Housing: Annual ceiling of 350 million dollars.

Retains statutory language on operating services and reserve funds. In cludes new language on of operating subsidy.

\begin{tabular}{|l|} 
\\
\end{tabular}

The Secretary is authorized to enter into contracts with state or local agencies approved by him to provide such agencies of the manageniont by private sponsors of projects assisted private spotion 502. Such assisted shall require th such agencies promptly report to the Secretary any deficiencies in the manasetary any cuch projects in order to enable of Secretary to take corrective the at the earliest possible time.
Public Housing: Same as S2182.

Public Housing: Same as S2182 and HR 10036.

Section 502: No operating subsidy.

Sections 235 and 236 deleted from statute.
Public Housing: Annual ceiling of 300 million dollars. Operating subsidy is conditional on the basis of establishment of (1) tenant eligibility criteria to assure a broad range of incomes and to avoid concentrations of very low-income and socially-deprived problem families: (2) satisfactory procedures to assure the prompt payment and collection of rents and for promipt processing of evictions in the case of ronpayment of rent; ( effective tenant' ships which asure and and project mainterance, and (t) a program the

pre "reserye funds."

Public Housing: "There are indications that even with improved management and a more realistic approach to rents, current federal subsidies may need to be adjusted to provide for continued operation and mintenance of existing projects." (President's message of September 19,1973.)

Annual maximum ceiling of $\$(n o$ figure).

Language on maintaining adequate operating services and reserve funds deleted.

No provision.

No provision. 
Prepared by NAHRO Policy and Research Division

\begin{tabular}{|c|c|c|}
\hline PROIISION & $\begin{array}{l}\text { Senate Bill: S2182, Housing Act of } 1973 \text {, introduced on behalf of } \\
\text { Senator John Sparkman (D-Alabama), July 14, } 1973 \text {. }\end{array}$ & $\begin{array}{l}\text { House Bill: HR10036, Housing and Lirban Development Act of 1973, } \\
\text { introduced by Congressmen William A. Barrett (D-Pennsylvania) and } \\
\text { Thomas L. Ashley (D-Obio) on September 5, 1973. }\end{array}$ \\
\hline Allocarion of Funds & 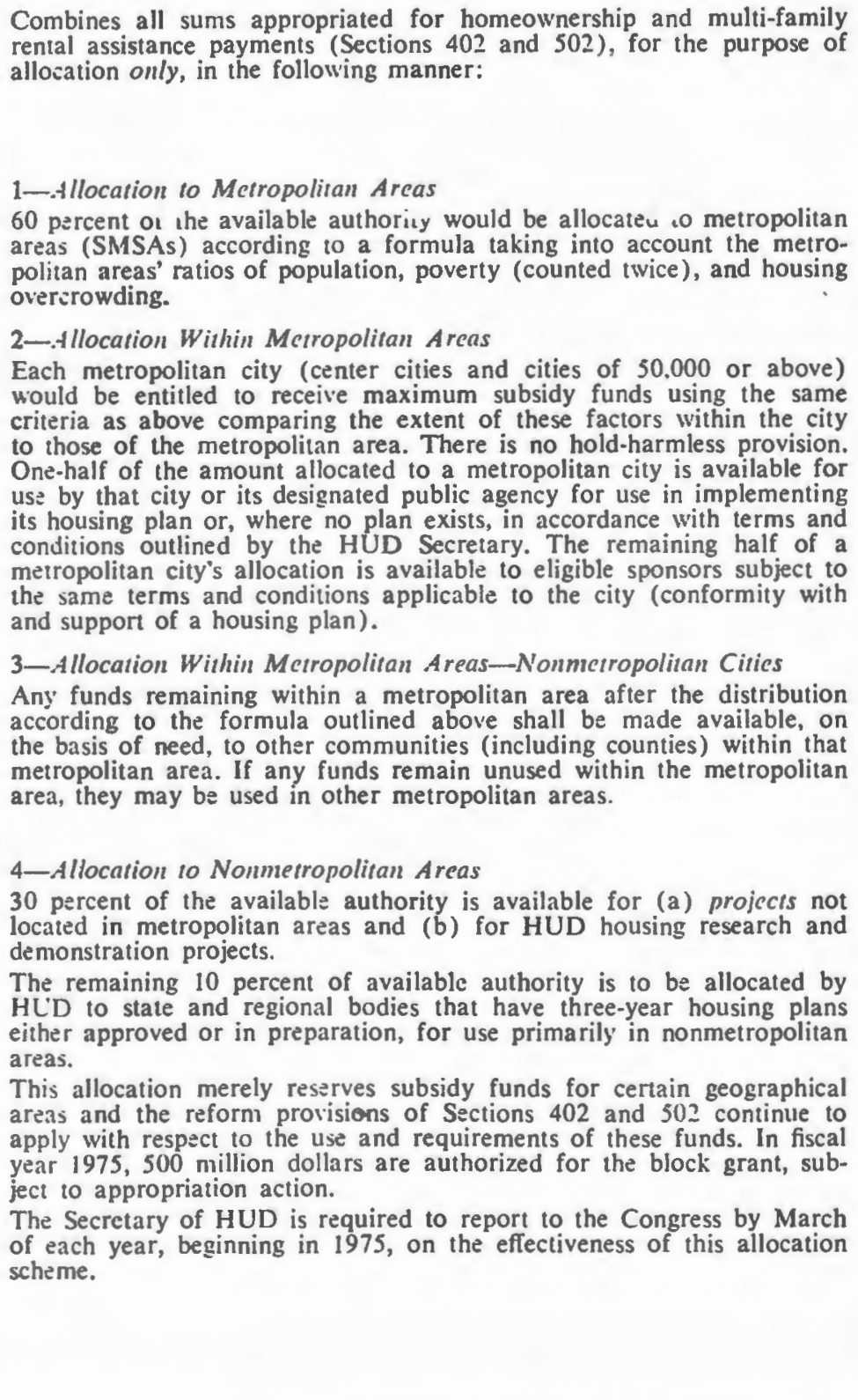 & 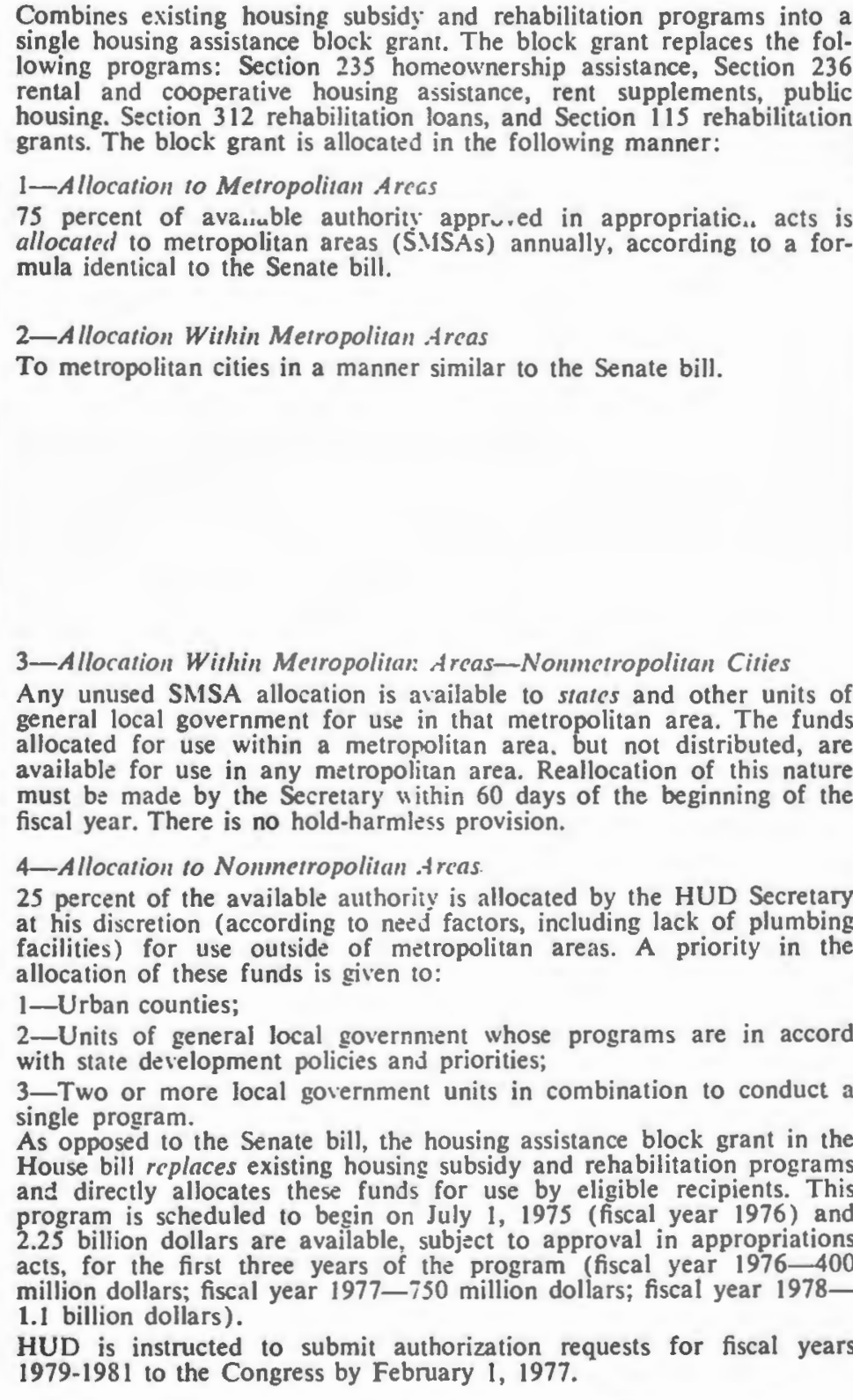 \\
\hline
\end{tabular}


Application Requirements

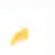

None of the block grant funds shall be made available to any state or regional body or unit of general local government unless the Secretary has received and approved a three-year housing plan submitted by that body or been given reasonable assurance that such a plan is under

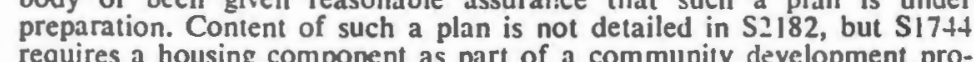
gram including meeting the housing needs of the community, including relocation and replacement housing for workers in connection, including government facilities especially for low- and moderate-income families.

Housing assistance block grants cover housing development and housing rehabilitation activities eligible under the Secton 402 homeownership assistance and Section 502 multi-family rental assistance housing programs.
The Secretary will not approve the allocation of any grant unless the cligible recipient has an approved application detailing:

1-The condition of the existing housing stock in the community and the housing needs of low- and moderate-income persons residing, employed, or likely to reside in the conmunity;

2-A housing program that takes into account the needs of all income groups and those displaced by government action and that advocates a balanced use of new and existing housing, where appropriate;

3-The type of assistance to be provided, estimated annual and longrange costs, the general location, and financing methods of projects;

4-How the housing assistance to be provided will further the objectives of local community development activities;

5-Compliance with appropriate civil rights legislation and facilitation of adequale cilizen participation in the development of the housing plan; 6 -Activities designed to facilitate freedom of choice in housing opportunities and to avoid undue concentration of assisted persons;

7-The availability of public fucilities and services to serve housing to be assisted; and

8-The commitment of state and local resources available in carrying out the program.

The Secretary shall evaluate a recipient's application annually and has the authority to make appropriate adjustments. In most cases. the Secretary will have to approve or disapprove an application within 60 days of the beginning of the fiscal year for which grants are made.

The following are eligible uses of the housing assistance block grant: 1-Rehabilitation grants for single-family, owner-occupied dwellings, to allow such property to conform to applicable code requirements;

2-Rehabilitation loans (including refinancing) to finance privatelyowred residential property;

3-Loans to finance the purchase, rehabilitation, or resale of one-tothree family divellings:

4--Periodic payments to reduce mortgage payments by up to 50 percent on one-to-three family owner-occupied homes;

5-Periodic payments to reduce rentals (and occupancy charges to mmmbers of cooperativ:s) in public and priv:"a projects;

6-Loans to finance the construction or purchase (with or without rehabilitation) of rental or cooperative projects;

7-Grants to reduce rentals in dwelling units leased by a public body or agency;

8-Modernization of rental or cooperative projects previously assisted by block grant funds;

9-Seed money to nonprofit organizations; and

10-Relocation payments and assistance, counseling, and tenant services, if not undertaken as part of a community development program.

Block grant funds used to finance activities 1, 2, or 3 above must be in connection with neighborhood rehabilitation programs. The Secretary, to the extent practical, shall encourage the utilization of private enterprise in the implementation of a community's housing assistance program. In addition, the Secretary may reserve housing assistance funds for use in approved new conmunity developments. 


\begin{tabular}{|c|c|c|}
\hline & Senate Bill: S2182 & House Bill: HR10036 \\
\hline $\begin{array}{l}\text { Eligible Housing Sponsors and } \\
\text { Financing Instruments }\end{array}$ & $\begin{array}{l}\text { The Secretary is authorized to guarantee taxable mortgage bonds issued } \\
\text { by or on behalf of local housing agencies or other state or local public } \\
\text { agencies approved by the Secretary, meeting the requirements of Section } \\
502 \text {. The Secretary is also authorized to make grants to any local hous- } \\
\text { ing agency or other state or local agency, the bonds of which are guar- } \\
\text { anteed in amounts not to exceed } 331 / 3 \text { percent of the interest paid on } \\
\text { such obligation. } \\
\text { The Secretary is authorized to insure mortgages of housing sponsors } \\
\text { currently eligible under Sections } 235 \text { and } 236 \text { housing programs, under } \\
\text { the same conditions. }\end{array}$ & $\begin{array}{l}\text { The Secretary is authorized to guarantee tax-exempt obligations of states, } \\
\text { units of general local government, or agencies thereof, under such } \\
\text { terms and conditions, and in such a manner as may be determined } \\
\text { by the Secretary. Obligations issued by such agencies which are taxable } \\
\text { may also be guaranteed and the Secretary is authorized to make grants } \\
\text { in an amount equal to } 30 \text { percent of the interest paid on such obliga- } \\
\text { tions. } \\
\text { The Secretary is authorized to insure mortsages of housing sponsors } \\
\text { currently eligible under Sections } 235 \text { and } 236 \text { housing prograns, under } \\
\text { the same conditions. }\end{array}$ \\
\hline $\begin{array}{l}\text { Stams of Local Housing } \\
\text { Authorities and Sections } \\
402 \text { and } 502 \text { Sponsors }\end{array}$ & $\begin{array}{l}\text { Local housing authorities would be authorized to issle taxable bonds } \\
\text { fnr new public housinr development and receive annual contributions } \\
\text { under the United States Housing Act of } 19 \text { s. The could also ve des- } \\
\text { ignated by general purpose local government to receive block grant } \\
\text { housing funds to develop housing under Sections } 402 \text { and } 502 \text {, issuing } \\
\text { taxable mortgage bonds for that purpose. Eligible housing sponsors un- } \\
\text { der the Sections } 402 \text { and } 502 \text { housing programs are eligibible only to pro- } \\
\text { cure funding under the block grant for housing. There is no separate } \\
\text { authorization for Sections } 402 \text { and } 502 \text { as there is for public housing. }\end{array}$ & 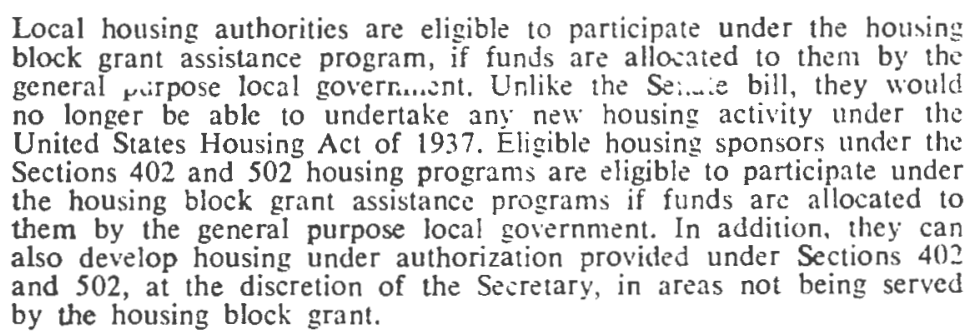 \\
\hline
\end{tabular}


ical community development grant and loan programs into a flexible and unified system of annual federal grants to local governments. Among those programs included in the consolidation were: urban renewal, model cities, neighborhood development program grants, open space land, urban beautification, historic preservation, public facilitiesloans, basic water and sewer facilities, and neighborhood facilities grants.

The Act stated that its primary objective was, "the development of viable urban communities, by providing decent housing and a suitable living environment and expanding economic opportunities, principally for persons of low and moderate income". It maintained that federal assistance would be available for the support of activities which were directed toward such objectives as:

The elimination of slums and blight and the prevention of blighting influences.

The elimination of conditions which are detrimental to health, safety and public welfare.

The Conservation and expansion of the Nations housing.

The expansion of the quantity and quality of community services.

A more rational utilization of land and other natural resources.

The reduction of the isolation of income grouns within communities and geographic areas. 
The restoration and preservation of properties of special value for historic, architectural, or aesthetic reasons.

The Act declared that states, cities, counties and other units of general local government were eligible as recipients of block grant funds but that entitlements would be determined through the use of a formula which was based on the areas population, the amount of housing overcrowding, and the extent of poverty, (which was to be counted twice). The total allocation for the first three years of the program was 8.4 billion dollars - with 2.5 billion dollars to be spent prior to the close of fiscal year 1975, and with 2.95 billion dollars to be spent during each of the fiscal years 1976 and 1977 .

Eighty percent of the funds would be distributed among metropolitan areas (SMSA's) and twenty percent among non-metropolitan areas. In addition, special provisions were made to continue to finance programs in areas which had been receiving funds through one or more of the defunct catagorical programs but which were no longer able to meet the eligibility requirements imposed by this Act. Such areas would be protected by this "holdharmless" provision and allowed to receive full funding for five years. At that point they would begin to receive a declining percentage ( 80,60 , and 40 percent) of the 
original amounts for a three year period.

The application process established in the legislation was greatly simplified in comparison to the previous categorical grant programs. However, localities were still compelled to demonstrate that their objectives were consistent with those of the overall federal effort in community development. Therefore, activities for which funding was available included:

The acquisition of real property which was:

blighted, deteriorated, deteriorating or inappropriately developed

appropriate for rehabilitation and conservation activities

appropriate for preservation or restoration of historic sites, urban beautification, conservation of open spaces, natural resources or scenic areas, provision of recreation, or the guidance of urban development

to be used for the provision of eligible public works, facilities, and improvements

to be used for other public purposes

The acquisition, construction, or installation of public works, facilities, and site or other improvements.

Code enforcement in deteriorated or deteriorating areas the result of which would arrest area decline.

The clearance, demolition, removal and rehabilitation of buildings.

Special projects to remove material and architectural barriers restricting mobility and accessibility. 
Payment to housing owners for losses of rental income while temporarily holding units to be used for relocation.

The disposition or retention of acquired real property.

Tre provision of public services not otherwise available in areas of concentrated activities if necessary to support specific activities.

The payment of non-Federal share in connection with other Federal programs undertaken as part of the development program.

Relocation payments and displacement assistance. The development of a comprehensive plan. Payment of administrative costs and carrying charges.

Localities were required to submit annual applications which indicated what progress they expected to make with the funds to be received; and, in the second year of the program, what progress they had achieved with the funds which they had received. This rigid adherence to federal objectives was stressed quite heavily in the legislation because, unlike several other major programs, no requirement for state or local contributions was made. Community Development Block Grants could be for up to one hundrea percent of the total cost of the project.

The specific requirements of the application included: 
(1) a summary of a three-year community development olan which identifies community development needs, demonstrates a comprehensive strategy for meeting those needs, and specifies both shortand long range community development objectives which have been developed in accordance with areawide development planning and national urban growth policies;

(2) formulates a program which (A) includes the activities to be undertaken to meet its community development needs and objectives, together with the estimated cost and general location of such activities, (B) indicates resources other than those provided under this title which are expected to be made available toward meeting its identified needs and objectives, and (C) takes into account, appropriate environmental factors;

\section{(3) describes a program designed to -}

(A) eliminate or prevent slums, blight, and deterioration where such conditions or needs exist; and

(B) Drovide improved community facilities and public improvements, including the provision of supporting health, social, and similar services where necessary and approbriate;

(4) submits a housing, assistance plan which -

(A) accurately surveys the condition of the housing stock in the community and assesses the housing assistance needs of lower-income persons (including elderly and handicapped persons, large families, persons displaced or to be displaced, and those expected to reside in the community),

(B) specifies a realistic annual goal for the number of dwelling units or persons to be assisted, including (i) the relative proportion of new, rehabilitated, and existing dwelling units, and (ii) the sizes and types of housirg projects and assistance best suited to the needs of lower-income persons in the community, and

(C) indicates the general location of proposed nousing for lower-income persons, with the objective of (i) furthering the revitalization of the community, including the restoration and rohabilitation of stable neighborhoods to the maximum extent possible, (ii) promoting greater choice of housing opportunities and avoiding undue concentrations of assisted persons in areas containing a high proportion of 
low-income persons, and (iii) assuring the availability of public facilities and services adequate to serve proposed housing projects;

(5) provides satisfactory assurances that the program will be conducted and administered in conformity with Public Law 88-352 and Public Law 90-284; and

(6) provides satisfactory assurances that, prior to submission of its application, it has (A) provided citizens with adequate information concerning the amount of funds available for oroposed community development and housing activities, the range of activities that may be undertaken, and other important program requirements, (B) held public hearings to obtain the views of citizens on community development and housing needs, and (C) provided citizens an adequate opportunity to participate in the development of the application."5

In addition, all applicants were bound to:

- comply with the Civil Rights Act of 1968

- Successfully complete an A-95 review of the CDBG application

- submit an annual performance report

The applications were to be submitted to the HUD area office which would review and evaluate the contents within a seventy-five day period. All applications were subject to the same criteria and would be approved unless:

- the description of community development and housing needs is plainly inconsistent with generally available facts and data;

- the activities proposed are plainly inappropriate to meeting stated needs and objectives; or 
- the application does not comply with the requirements of Title I or other apnlicable law, or proposes ineligible activities.

Housing Assistance Plans

As stated, among the primary objectives of the Act were the desires to create decent housing, suitable living environments, and expanded economic opportunities, principally for persons of low- and moderate-income. Congress realized that the degree of success which it could expect to achieve was contingent upon its ability to create a comprehensive program which addressed the numerous problems confronting lower-income groups. The legislation therefore sought to insure that localities made a definitive commitment towards achieving this goal.

It was determined that the manner in which this should be accomplished was to provide adequate housing for low- and moderate-income grouns within the geographic area which was scheduled for redevelopment. The underlying intent was to guarantee that such groups shared directly and equally in the economic prosperity which would supposedly develop as a result of the program. This aspect of the program was substantially different from its predecessors - urban renewal had become infamous as a mechanism used to remove lower-income groups from 
areas scheduled for redevelopment.

The Housing Assistance Plan (HAP) therefore became, in theory, a crucial component of the application process. No Community Development Block Grant (CDBG) would be approved without it, and, in addition, it would be used to govern HUD's approval of any subsidized housing project proposed under Title II of the Act - "Assisted Housing" - otherwise known as the "Section 8" housing program. Specifically, Section 213 (d) (1) of the Act required that HUD "...consider the relative needs of different areas and communities, as reflected in data as to population, poverty, housing overcrowding, housing vacancies, amounts of substandard housing, or other objectively measurable conditions", in determining allocations of federal housing subsidies. It was also compelled to consider those goals proposed by the locality to meet lower-income housing needs as they were specified in the housing assistance plan. This requirement became significant in that the Section 8 program had been alloted nine-hundred million dollars for distribution and would become the primary vehicle for housing; assistance.

Yet the specific data required by HUD could unwittingly undermine a basic objective of the Community Devel- 
opment Act. The information gathered had a tendency to reflect the needs of people in the areas in which they were currently living and not in the areas from which they were excluded. Therefore, housing, programs developed on the basis of this data might well continue to restrict the mobility of low- and moderate-income families.

Unfortunately, there were other problems oresented in the early years of the HAP program which further restricted its ability to assist in the accomplishment of the goals stated in the Community Development Act.

Foremost among these was simply the era in which it was born. The senate, the House of Repressentatives and the Administration had fought over several alternatives for approximately four years. During this time funds for housing and community develonment programs had been repeatedly reduced, and those which remained offered little in comparison to the amount actually needed. The increasing disenchantment among the parties involved in the process seemed to culminate in January, 1973, when the moratorium was imposed by the Nixon Administration. The result of this action was to upset not only the disenfranchised client group, but all those involved in the process of providing such a service. The public housing 
programs were suspended for a period of eighteen months, and that action provided the catalyst required to create a substantial amount of frustration. Therefore, when the controls were lifted and substantial new funds were allocated for housing and community development programs, it was reasonable to expect that a considerable amount of pressure would be brought to bear in order to get those funds released.

However, any attempt to explain HUD's performance in the supervision and evaluation of the Housing Assistance Plan program, and therefore their ability to uphold the principle expressed in the Community Development legislation, must remain largely based in speculation. The Department of Housing and Urban Development official position, as reflected by Secretary Carla A. Hills, maintained that, overall, the CDBG program was a "considerable success" which had "...significantly increased the ability to respond effectively to local Problems".

A few CDBG program administrators have been slightly more candid in admitting that HUD, in 1975, was faced with a program which was so new and dramatically different from orevious efforts that they were not fully prepared to deal with the specifics of such requirements as the Housing Assistance Plan. 
Elsewhere, however, there were individuals who were sufficiently removed f'rom the Department's sphere of influence to be, perhaps, somewhat less self-serving in their critique of the evaluation process. In the final report of a year long study on the performance of the HAP program one such organization stated that:

"The significance of the Housing Assistance Plan as a local commitment to undertake lowerincome housing programs or to accomodate such housing sponsored by private parties has been seriously reduced by HUD's near-automatic approval of submitted plans despite serious deficiencies. The potential use of such plans to judge the acceptability of specific housing proposals in the future and the performance of communities seeking future continuation of community development grant funds is being compromised by uncritical acceptance of inadequate plans."7

In an unacceptably large number of cases it, was reported that HUD approved local HAPs which contained information that was "...plainly inconsistent with generally available facts and data" and, also, "... plainly innapropriate in meeting the stated needs and objectives of the area".

Three agencies serving the Boston, Massachusetts area: The Department of Community Af'airs (DCA); The Massachusetts Housing Finance Agency (MHFA); and 'The Massachusetts Commission Against, Discrimination (MCAD); undertook a review of thirty-nine HAPs submitted in 
conjunction with CDBG applications and determined that thirty-four of these failed to reflect an appropriate balance between the amount of housing planned for the elderly and that planned for families. In addition, MHFA went on to state that local goals, as reflected in the HAP's were inconsistent with those established for the area. Yet, HUD proceeded to approve the HAPs, despite the objections raised, andclaimed that they would be more critical in their review of the following years' applications.

Documentation such as that presented in Boston, and elsewhere, demonstrated that little attention was paid to the role of the area-wide reviewing agency. Negative remarks from such agencies were frequently dismissed with no comment at HUD, and at no point during the first year of the program did HUD attempt to solicit the assistance of such organizations in developing a comprehensive approach to providing housing in the areas which they served.

A related instance occurred in the area of Hartford, Connecticut, yet the result was somewhat different. Although the issue in the City of Hartford v. Hills case was not resolved until 1976 by the United States District Court for the District of connecticut, it brought 
to a climax an argument that was heard in literally dozens of other localities. In this case the City of Hartford and representatives of the lower-income groups charged that HUD had failed to adhere to the statutes surrounding the Community Development Act in that, they had approved Housing Assistance Plans which offered no information concerning that group of low-income persons "expected to reside" in the area. The court agreed that an exclusion such as this violated the statutes, and it enjoined the six towns which had been listed as defendants from completing the projects as planned.

A seventh defendant in the case presented a slightly different problem. The town of East Hartford had submitted a HAP which contained a figure in the "Expected to Reside" column; however, the vlaintiffs maintained that the figure had drastically understated the actual situation, and they sought to block completion of the accompanying community development project charging that the decision to approve the plan was based on arbitrary and capricious standards. In the decision delivered by the court it was stated that:

\footnotetext{
"The statutes require me to determine, in
} essence, whether the decision (to approve the grant) was based on a consideration of the relevant factors and whether there has been a clear error of judgement. ...I conclude that the Secretary (of HUD) has abused her discretion in both respects. 
There is no doubt that HUD did not conduct a rigorous review of the East Hartford "expected to reside" projection. [t justified this failure by pointing to an alleged absence of data. In fact, however, a wide variety of alternative data sources was available." 8

It appears as though there is no shortage of inconsistencies in the reviewing process. For example, in a somewhat reversed situation, a suburb of Atlanta, Georgia was granted 175,000 dollars in Section 8 housing subsidies when no such request was included in the HAP which they submitted. In other instances, applications were routinely approved which provided additional funds for the construction of housing units for low-income persons in areas that were already predominantly occupied by minority members with low- or moderate-incomes.

Such incidences provided strong indication that HUD failed to comply with or enforce a second major objective of the Community Development Act - the reduction of the isolation of income and minority groups within communities and geographic areas. These circumstances held the potential to substantially diminish the overall effectiveness of the HAP program and served to question the validity of the block grant programs' attempt to relate housing and community development activities in a comprehensive manner. 
This situation was exacerbated by the regulations which governed the administration of the Section 8 Housing Assistance Program. A family seeking to acauire housing under the section 8 program was required to obtain a Certificate of Family Participation from the local public housing authority (PHA) or - where no PHA or other HUD representative existed - from HUD directly. The PHA, in turn, would reserve a portion of its total allocation of rent subsidies for each certificate issued. The family was instructed to locate a dwelling unit which met its own individual requirements and told that it had sixty days in which to do so. The certificate thus enabled the recipients to negotiate a lease anywhere within the jurisdiction of the issuing PHA.

However, the acceptance of a specific unit might restrict the future mobility of a family in ways never intended in the original legislation. A family wishing to move from one location to another within the same jurisdiction was required to obtain a second Certificate of Family Participation. Yet, its issuance was contingent upon the general availability of additional certificates. Each PHA was empowered, under contract authority from HUD, to issue only a specific number of certificates and when it had exhausted its annual allocation it was left without the prerogative to approve transfers. 
The validity of the regulations which encompassed a program that purported to maximize the mobility of lower-income families became subject to further question in the matter of aiding movement between PHA jurisdictions. Although no family was outrightly prohibited from engaging in such movement, they were restricted under a series of inexplicit and apparently self-defeating regulations which served to frustrate such activity by failing to provide a formal administrative mechanism which addressed this situation.

The Housing Assistance Program regulations were written so as to provide that each independent PHA would retain exclusive control over the housing program within its jurisdiction. Therefore, a family wishing to move from one jurisdiction to another might be compelled to terminate its agreement with one PHA in order to fulfill the requirements for eligibility with another. A family could conceivably be compelled to terminate their existing agreement solely in order to gain access to a waiting list of a PHA in another area. Yet perhaos the greatest obstacle to mobility existed in the fact that the regulations did not prohibit the local PHAs from restricting access to those who were already residing within the PHA's jurisdiction. 
The objectives of the Housing Assistance Frogram were further hampered by prolonged delays in the application review and approval process. The Department of Housing and Urban Development consistently failed to effectively implement directives issued by congress and the Administration.

It had become obvious, in the fall of 1973, that congressional hearings on alternative proposals for community development legislation would continue for longer than had originally been anticipated. President Nixon therefore decided, in September of that year, to release 100,000 units of Section 23 housing (the immediate predecessor to section 8 housing) in an attempt to ease the burden on a variety of interested parties. HUD was instructed to complete contracts for 50,000 units of new construction and 50,000 units of existing housing by July 1,1974. Yet, by August, 1974, it had aporoved proposals for only 1,719 units, or less than two percent of the total allocation, and no construction had actually begun

This situation continued under the new Section 8 program which became effective as the Community Development Act of 1974 was signed into law on August 22. The legislation made provisions for the release of 400,000 
units of Federally subsidized housing and HUD estimated that it would have accomplished by July I, 1975:

- The start of construction or rehabilitation on 55,000 units, with 50,000 ready for occupancy; and,

- Contracts approved for an additional 200,000 units.

However, when that date apoeared no construction had begun and only 95,694 units, or less than fifty percent, were actually under contract. By October, 1975, only 113,700 reservations had been approved - 45,000 of which were for new or rehabilitated units and 68,600 of which were for existing units - fifty percent of which, overall, were for elderly housing.

The Housing and Community Development Act of 1977

HUD's performance during the first three years of the community development program led many local officials to question the appropriateness of a program which sought to link housing and community development activities. The true depth of resentment to the Housing Assistance Plan Program became apparent during hearings before the Subcommittee on Housing and Community Development in February and March of 1977. The Subvommittee had met to consider the restructuring and continued funding of 
the Community Development Act, and it was not long after the hearings had opened that it became apparent that changes would have to be made.

Although the vast majority of time was spent discussing such issues as the adootion of a new funding formula, the individual needs of small communities, the Urban Development Action Grant Program, and expanded citizen participation requirements, there was developed a specific list of grievances concerning the Housing Assistance Plan and it was portrayed by many as one of the most controversial requirements of the original Act.

In addition to those problems cited above, it was noted that substantial variation existed in the various HUD Area Offices' ability to assist apolicants in the development of their HAPs. This variation obviously also existed in their evaluation capabilities and both inconsistencies were thought to have occured largely as a result of insufficient guidance from Department Headquarters.

Widespread criticism also centered on the belief that the number of Section 8 allocations which were made available were far below what was actually required in order to fully confront the problems of insufficient and sub-standard housing. In fact, it was stated that 
HUD frequently required that HAPs be revised in order to reflect a more reasonable percentage of the number of units that it was know or indicated would become available.

It was also stated that the Fair Market Rents that had been established by HUD were inadequate and unrealistic; and, that because the mortgage market was currently restricted the contract terms for loans should be extended from twenty to thirty years. Finally, it was made known that there existed, on the local level, a lack of local strategies with which to bring the two programs together and that data and survey techniques were not well developed.

These arguments were presented to both the House and Senate during their respective hearings but their reception produced substantially different results. Although the House had originally proposed the inclusion of a HAP as an application requirement, it would suggest no revision in substance of procedure to address the problems brought to its attention. The Senate, on the other hand, did consider it necessary to revise the HAP and offered the following suggestions for change:

\footnotetext{
"Require the housing assistance plan to:
} 
(1) Identify housing stock which is deteriorated or likely to deteriorate and to provide for the reclamation of such housing where feasible through the use, by local government, the private sector, or community organizations, of a broad range of housing restoration techniques, including aquisition and rehabilitation;

(2) include adequate provision to insure that the preponderance of families benefiting from subsidized housing rehabilitation is of low and moderate income, and that a reasonable proportion of rehabilitated units is set aside to give tenants displaced as a result of the rehabilitation efforts an opportunity to be relocated in their immediate neighborhood; and

(3) designate, to the maximum extent practicable, one or more areas where housing rehabilitation and neighborhood revitalization will be concentrated." 9

Once again two alternatives had emerged from the Congress and it was necessary to send the resolutions to a Committee of Conference in order to derive a unified proposal which could be forwarded to the Administration.

The committee of Conference chose to adopt the suggested liAP revisions proposed by the Senate, and they were therefore included in the document which President James E Carter signed into law on October 12, 1977. The Community Development Act of 1977 would provide substantial new funding in an attempt to further both old and new objectives. The congress had allocated 3.5 billion dollars for spending in fiscal year 1973 and 3.65 billion 
dollars for each of the fiscal years 1979 and 1980 .

The Housing and Community Development Amendments of 1978

The Housing and Community Development Amendments hearings of 1978 were convened by Congresss in order to consider both the extension of a series of basic authorities provided under previous legislation and the continued funding of a variety of assisted housing and other programs which were scheduled to expire. The hearings also provided an opportunity to reflect on comments which had been made about the Housing Assistance Plan Program since it had undergone revision in 1977 and to suggest further changes which might make it more responsive to the original objectives of the Community Development Act.

The hearings produced two recommendations for revision. Both Houses proposed that communities should include within their plan the relative proportion of existing rental and owner-occupied units to be upgraded and thereby preserved; and, the Senate proposed that owners of homes requiring rehabilitation assistance be added as a category of low-income persons to be assessed. The Committee of Conference selected both provisions for inclusion in the final amendments and they were thus incorporated in the Act which was signed into law on 
October 31, 1978. 
Footnotes

1. William A. Barret, "Opening Remarks", Hearings of the Subcommittee on Housing of the Committee on Banking and Currency, U.S. House of Representatives, (Washington, D.C.: GPO, 1973).

2/3. The Board of Governors of the National Association of Housing and Redevelopment Officials, "NAHRO Calls for Immediate Responsible Action", Journal of Housing, 31, No. 4, (1974).

4. James H. Blair, "Positive View of Fair Housing opportunity Provisions of the Housing and Community Development Act of 1974 Urged", Journal of Housing, 33, No. 3, (1976).

5. U.S. Congress, The Housing and Community Development Act of 1974 - Public Law 93-383, (Washington, D.C.: (PPO, 1977).

6. Carla A. Hills, "Fair Housing is Everybody's Business", HUD Challenge, VII, No. 4, (1976).

7. Herbert M. Franklin and Arthur J Levin, "The Housing Assistance Plan: A Non-Working Program for Community Development", (The Potomac Institute: Washington, D.C.,1975).

8. District Judge Blumenfeld, "City of Hartford v. Hills", U.S. District Court, District of Connecticut, 408 F. Supp. 889, (1976).

9. U.S. Congress, Compilation of the Housing and Community Development Act of 1977, (Washington, D.C.: GPO, 1977 ). 
CHAPTER IIT. 
CHAPTER THREE

Housing Assistance Plans are not universally required, but only as a part of any Community Develonment Block Grant (CDBG) apolication. A community satisfied with general revenue sharing and/or other Federal programs and funds need not express housing needs or goals in this form or at a 13 . Few individual communities receive "70l" comprehensive planning funds directly so have little or no incentive to complete or update master plans, housing elements, "workable programs" for categorical grants assistance, or other analagous predecessor mechanisms alternative to the HAP. Analysis of all the HAPs in Rhode Island submitted to date reveals that most communities have submitted at least one. The "carrot" of' CDBG funding has been effective to the extent that cities and towns are provided the opportunity, incentive or "stick" necessary to express their housing needs and goals. 
Table I indicates participating communities in

Rhode Island by date(s) of application or applicability.

It is not required that HAP's be resubmitted until or

unless circumstances chanoe or communities wish to annlv for additional or different fundinr. Earlv submissions. therefore, remain current or in effect. 
TABLE I

R.I. Communities with Housing Assistance Plans

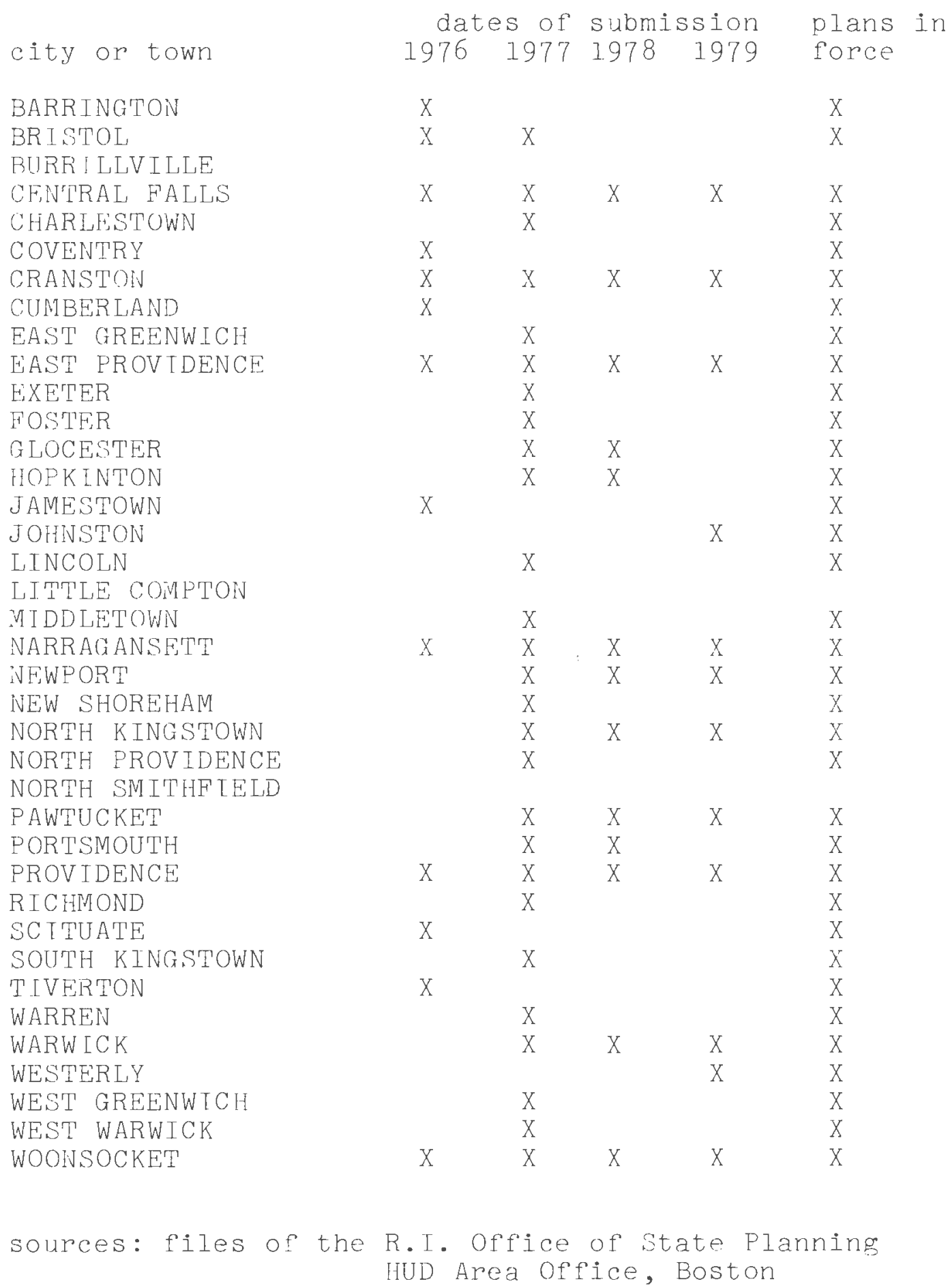


The Housing Assistance Plan consists of several required elements:

I. Survey of Housing Conditions. Units occupied and vacant, standard and substandard, owner occupied and rented, and those suitable for rehabilitation.

I . Housing Assistance Needs of Lower Income Households. Households in need by tenure (owner or renter), by household type (elderly and handicapped, small family, large family), by minority group status and by sex (female headed households), and households anticipated (expected to reside).

III. Goals for Housing Assistance. Annual (current year) and three year goals for households assisted by tenure, by program type and form of assistance (new construction, rehabilitation and/or subsidy of existing housing units), and by household type and size.

IV. General Locations for Proposed Lower Income Housing. Maps and/or narrative describing census tracts where new construction or rehabilitation is proposed.

While the forms required and the format of data have been changed in almost every program year, the basic elements have remained essentially the same. New forms and formats have also apparently provided for emphasis upon various elements such as minority and female headed 
households, the relative percentages proposed for elderlyand handicapped as opposed to family units, and the percentages proposed by tenure and types of assistance, new construction, rehabilitation or existing unit subsidy. It is not felt that such changes have had any dramatic impact upon the number or content quality of HAPs filed, except to the extent that they confuse and confound the persons preparing them or attempting to aggregate data from them. Variations in the location of information on the forms over the years no doubt increases the possibilities for errors in tabulation and aggregation of data.

The use of terms like "suitable for rehabilitation," "expected to reside," "needs" and "goals" immediately require that analysis include a variety of normative considerations. They indicate the ability of communities to indicate what they want and where they want to go as well as reflect national priorities, requirements and availability of program assistance.

The legislation of recent years has had the admirable goal of linking and coordinating housing and community development funding and activity in a more comprehensive way. The goal of the authors would be to seek an even greater definition of comprehensiveness which would 
incorporate other social wellare concerns, to encompass income transfer programs, employment and economic and educational opportunity. Communities, on the other hand, seem to be headed in exactly the opposite idrection with competeing and conflicting agencies for housing and for community development (the Providence Housing Authority versus the Mayor's Office of Community Development, for example). Smaller towns require that planner(s) spend but a part of a work day or work year in HAP and CDBG activity with a myriad of other concerns making coordination and comprehensiveness impossible.

This study is most concerned with housing as opposed to overall community development need and effort. Within the context of the HAP, it has further distinguished and analyzed needs and goals for the provision of rental units and subsidies as opposed to funds for the rehabilitation or repair of owner occupied units, Section 312 rehabilitation, free paint programs and the like. This has been done because the latter, while important in even a limited "comprehensive" view, make comparison across communities and within them numerically misleading. For example, a city wide code enforcement or free paint program may provide "assistance" to large numbers at low cost, bu it has little or no impact on the needs of renters for assistance in the form or new or newly subsidized units. 
The focus, then, will be upon the "needs" and "goals" sections of the HAP with attention to the so-called "deep subsidy" programs, those which cost much more because they provide direct and long term impact upor the availability and affordability of units. This form of analysis best provides an indicator of community intent and participation in the social welfare goals of the legislation of 1974 and subsequently- "promoting increased housing choice.."

Methodology

Data has been aggregated and displayed according to the six housing market areas in Rhode Island developed by the R.I. Department of Community Affairs (DCA) and utilized by HUD and the State Housing Plan. This ensures that the analysis can be more easily compared and contrasted with past, present and future housing research in the state.

In most cases, the information presented is in terms of percentages of state totalsfor several reasons:

(1) It seems to provide the simplest means for comparison across the state, where the population and numerical representations of data have a substantial range. 
(2) The qualitative and normative implications of data areat least as important and probably more significant and are more understandable in this format than in numeric displays alone.

(3) There exists considerable variability in the sophistication of methodologies employed and staff ability or willingness to prepare HAPs in a fashion which lenas itself to comparison across communities.

It is difficult to elaborate much further on this last point without disparaging the intent or competence of some preparers. Examples of the sources of statistics used in HAPs include "guesstimates," "informed" local sources, ratios applied to all but entirely arbitrary totals, through some fairly sophisticated techniques but using somewhat dated information bases. It is felt that our aggregation of data and conversion to percentages will have the desired effect of "flattening" some of the unanticipated imprecision in method and human error, including our own.

Need

In this, as in other aspects of the CDBr process in general and in the case of the HAP, HUD regulations 
"reqlire" but they also "allow." That is, methodology may be suggested, but deviations are permitted to allow local information gathering and flexibility. This latitude has led to both expansion and contraction of communities' stated or perceived need. HUD judges the HAP to be "acceptable" or "not acceptable" but not "accurate" or "true." What follows, then, is considerable variation and consequent understatement or overstatement of need relative to independent, if not necessarily objective, standards of need which may be applied uniformly from community to community throughout the state.

For the purposes of the HAP, lower income households are those whose incomes are less than eighty per cent, of the median for the area; it is the same definition as that used in the Section 8 Housing Assistance Payments program. The number of households within this limit, indicates those eligible rather than in immediate need. It must be adjusted to account for those of low income who may already occupy decent affordable housing. The definitions for "standard" and "affordable" relate to the familiar but probably inadequate criteria with respect to the lack of one or more plumbing facilities, 1.01 persons per room and an income-rent ratio of more than twenty five percent. 
Because of the difficulties inherent in using certain census tabulations, at least one community reduced its eligibility figure by an arbitrary one to two thirds to allow for double counting of low income houscholds, those with inadequate shelter and/or paying excessive rent. Another merely requested the housing authority to provide the number on the "waiting List." In a town where there was no subsidized housing, the number on a probably non-existent waiting list is all but meaningless. On the other hand, some cities, especially those with code cnforcement or inspection staffs or aggressive community development agencies) are permitted to use locally developed criteria which may increase the number of units considered substandard by considerable proportions. Tf state and local code violations as well as the census definitions are taken into account, one may expect to find the percentage of substandard dwelling doubled or even increased by a factor of three or four.

Here it is necessary to confront one of the problems central to the housing and community development process as it has operated since 1974. The changes in application procedures as well as in the forms of assistance provided have promoted flexibility in the competition for funds. This "competition" however is not a 
race among equals or among those with similar intent and motivation. Cities and towns do not react with equal enthusiasm to the prospect of low income housing. Considerable aggressiveness has been shown on the part of some larger communities, especially for relatively trouble free housing for the elderly. This has been done not only as a social program but also as a tool for economic development, neighborhood revitalization, and more than occasionally considerable political and financial gain for some of the participants. This is in sharp contrast to the near hysteria on the part of some small town officials when presented with proposals for similar projects. In less obvious ways, some officials will both overstate or understate goals. In other cases, they may even be unaware of doing so. As a result, some alternative standards or indicators are examined below.

In 1973, the Rhode Island Department of Community Affairs prepared a document entitled "Housing Need for Low and Moderate Income Households" which used 1970 census data cross tabulated for the components of need specified in HAP regulations- income, housing condition, and percentage of income spent on rent. It used, however, public housing income limits to describe low income 
households and section 235 and 236 limits to define moderate income. As a result, it substantially underestimates need as allowed or allowable under current regulations. Nevertheless, the percentages derived are viewed as a reasonable "benchmark" against which Rhode Island communities may be compared. Some cities and towns have used the DCA figures to represent total need, renter need with or without adjustment, or not at all with consequent overstatement, or understatement relative to this measure.

other indicators are provided for comparison. 1970 census income data was used in the following fashion. The median income in the state was then $\$ 9736$; eighty per cent of that would be $\$ 7788$; the next lower "breakpoint" in easily accessible data was the number and percentage of households earning less than $\$ 7000$ per year. It is felt that as an indicator if not true measure of need, this figure may be used as it provides for some, if imprecise, adjustment for the gap between those eligible and those in current or immediate need. The record demonstrates that HAPs have been approved with far less precision or justification.

Another, somewhat fixther removed indicator may be derived from the public assistance records of the Rhode 
Island Department of Social and Rehabilitative Services and the Social Security Administration. Again, readily available but infrequently utilized statistics concerning the average Aid to F'amilies with Dependent Children (AFDC) and Supplemental Security Income (SSI) caseloads for fiscal years 1973-1979 may provide, as a social indicator and quality of life measure, a basis for comparison with HAP submissions. Virtually all public assistance recipients are income eligible and most outside of public housing pay in excess of twenty-five per cent of income for rent. Again too, the numbers are intentionally likely to underestimate true need as many more households not on assistance are eligible, and not all forms of transfer payments have been considered. Omissions include "temporary" measures such as unemployment compensation ard general public assistance.

It should be recognized that the time and financial resources of this project do not permit a full scale multiple regression or social indicator analysis, but it is felt that such methodology might profitably be employed in the refinement of the current analysis.

Table II compares and contrasts Rhode Island city and town determinations with other standardized measures which might have been used or indicators which are available. 


\section{TABLE IIa}

HAP Statements of Need and other Measures or Indicators (percent of state total)

METROPOLITAN CORE MARKET AREA

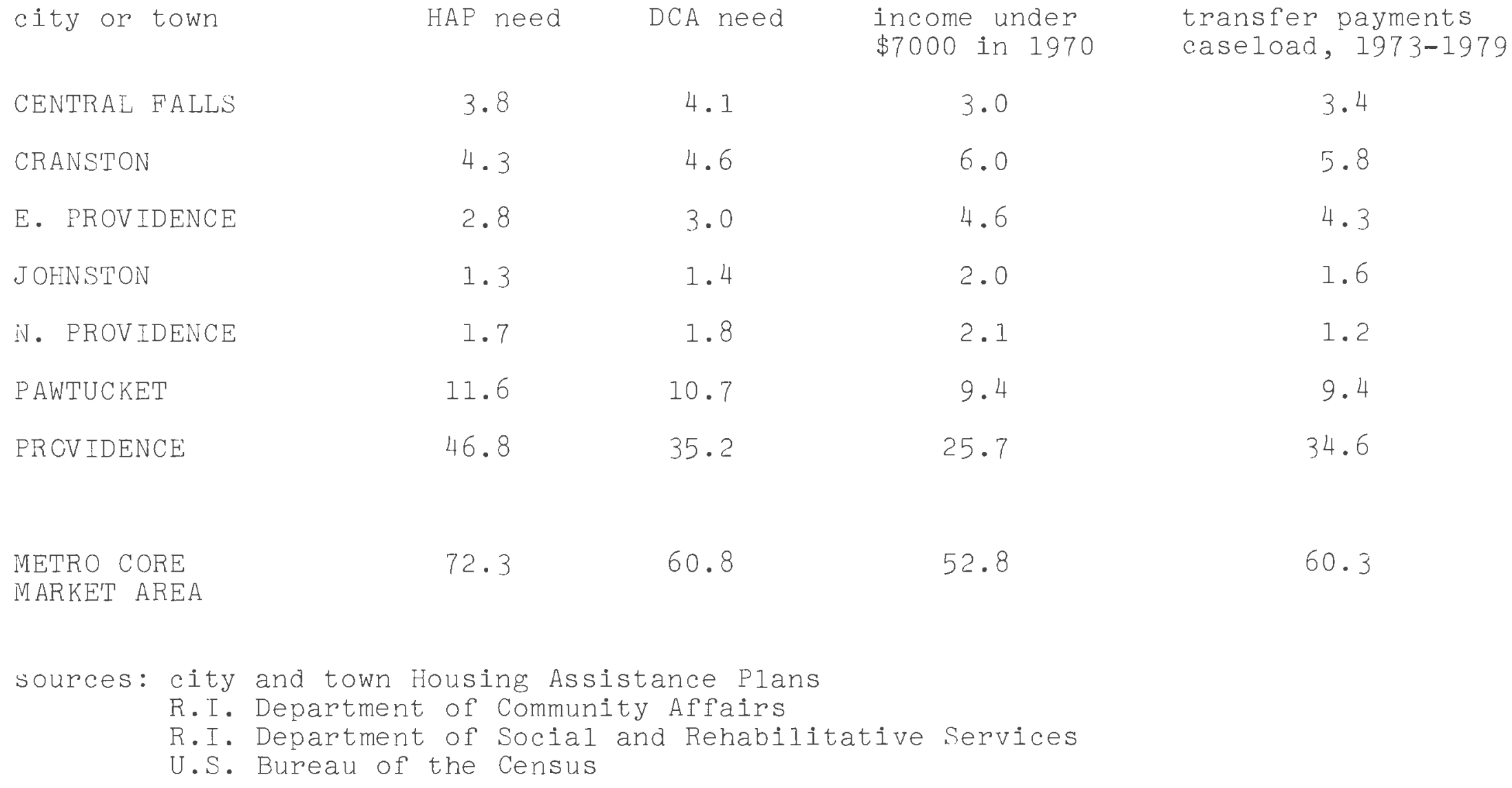




\section{TABLE IID}

HAP Statements of Need and other ileasures and Indicators (percent of state total) NORTHERN R.I. MARKET AREA

\begin{tabular}{|c|c|c|c|c|}
\hline city or town & HAP need & DCA need & $\begin{array}{l}\text { income under } \\
\$ 7000 \text { in } 1970\end{array}$ & $\begin{array}{l}\text { transfer payments } \\
\text { caseload, 1973-1979 }\end{array}$ \\
\hline CUMBERLAND & $\cdot 3$ & .9 & 1.6 & 1.2 \\
\hline LINCOLN & $1 \cdot 3$ & 1.1 & 1.6 & .8 \\
\hline N. SMITHFIELD & $n / a$ & .6 & .7 & .2 \\
\hline SMITHFIEID & .4 & .6 & .8 & .7 \\
\hline WOONSOCKET & 3.8 & 6.0 & $6 \cdot 3$ & $7 \cdot 9$ \\
\hline $\begin{array}{l}\text { NORTHERN R.I. } \\
\text { MARKET AREA }\end{array}$ & 5.8 & 9.2 & 11.0 & 10.8 \\
\hline
\end{tabular}




\section{TABLE IIC}

HAP Statements of Need and other Measures and indicators (percent of state total) WESTERN R.I. MARKET AREA

$\begin{array}{lcccc}\text { city or town } & \text { HAP need } & \text { DCA need } & \begin{array}{c}\text { income under } \\ \$ 7000\end{array} & \begin{array}{c}\text { transfer payments } \\ \text { caseload, }\end{array} \text { 1973-1979 } \\ \text { BURRILIVILIE } & \text { n/a } & 1.1 & 1.0 & 1.3 \\ \text { COVENTRY } & .7 & 1.1 & 1.6 & 1.8 \\ \text { EXETER } & .3 & .2 & .3 & .2 \\ \text { FOSTER } & .3 & .1 & .3 & .2 \\ \text { GLOCESTER } & .5 & .3 & .5 & .4 \\ \text { SCITUATE } & .1 & .5 & .6 & .5 \\ \text { W. GREENWICH } & .2 & .2 & .2 & .1 \\ & & & & 4.5 \\ \text { WESTERN R.I. } & 2.1 & 3.5 & 4.5 & \end{array}$


TABLE IId

HAP Statements of Need and other Measures and Indicators (percent of state total) WEST BAY MARKET AREA

city or town

E. GREENWICH

N. KINGSTOWN

WARWICK

W. WARWICK

WEST BAY

MARKET AREA
HAP need

DCA need

1.1

$2 \cdot 9$

3.8

2.6

2.0

7.8

10.4

$12 \cdot 9$

2.9 transfer payments

caseload, 1973-1979
.7
1.6
6.0
2.6

10.9 
TABLE IIe

HAP Statements of Need and other Measures and Indicators (percent of state total) EAST BAY MARKET AREA

\begin{tabular}{|c|c|c|c|c|}
\hline city or town & HAP need & DCA need & $\begin{array}{l}\text { income under } \\
\$ 7000 \text { in } 1970\end{array}$ & $\begin{array}{l}\text { transfer payments } \\
\text { caseload, } 1973-1979\end{array}$ \\
\hline BARRINGTON & .4 & $\cdot 5$ & .9 & .4 \\
\hline BRISTOL & 1.2 & 1.4 & 1.8 & 1.5 \\
\hline JAMESTOWN & .2 & $\cdot 2$ & $\cdot 3$ & .2 \\
\hline LITINE COMPTON & $\mathrm{n} / \mathrm{a}$ & .2 & .2 & .1 \\
\hline MIDDLETOWN & 1.5 & 2.1 & 2.0 & 1.2 \\
\hline NEWPORT & 2.0 & $3 \cdot 2$ & 4.4 & $3 \cdot 5$ \\
\hline PORTSMOUTH & .9 & 1.0 & 1.5 & .6 \\
\hline TIVERTON & .5 & .9 & 1.2 & .8 \\
\hline WARREN & .8 & 1.2 & 1.2 & .9 \\
\hline $\begin{array}{l}\text { EAST BAY } \\
\text { MARKET AREA }\end{array}$ & 7.5 & 10.7 & 13.5 & 9.2 \\
\hline
\end{tabular}


TABLE IIf

HAP Statements of Need and other Measures and Indicators (percent of state total) SOUTHERN R.I. MARKET AREA

$\begin{array}{lcccc}\text { city or town } & \text { HAP need } & \text { DCA need } & \begin{array}{c}\text { income under } \\ \$ 7000\end{array} & \begin{array}{c}\text { transfer payments } \\ \text { inseload, } 1973-1979\end{array} \\ \text { CHARLESTOWN } & .2 & .2 & .4 & .1 \\ \text { HOPKINTON } & .5 & .4 & .5 & .4 \\ \text { INARRAGANSETT } & .4 & 1.1 & .8 & .4 \\ \text { iNEW SHOREHAM } & .1 & .1 & .1 & 0 \\ \text { RICHMOND } & .4 & .4 & .3 & 1.4 \\ \text { S. KINGSTOWN } & 1.6 & 1.6 & 1.3 & 1.3 \\ \text { WESTERLY } & 1.5 & 1.6 & 1.7 & \\ & & & & 3.9 \\ \text { SOUTHERN R.I. } & 4.7 & 5.5 & 5.1 & \end{array}$


TABLE IIg

HAP Statements of Need and other Measures and Indicators (percent of state total) R.I. MARKET AREAS

market area

METRO CORE

NORTHERN R.I.

WESTERiv R.I.

WEST BAY

EAST BAY

SOUTHERN R.I.

$\begin{array}{rr}\text { HAP need } & \text { DCA need } \\ 72.3 & 60.8 \\ 5.8 & 9.2 \\ 2.1 & 3.5 \\ 7.8 & 10.4 \\ 7.5 & 10.7 \\ 4.7 & 5.5\end{array}$

\begin{abstract}
income under $\$ 7000$ in 1970
\end{abstract}

52.8

11.0

$4 \cdot 5$

$12 \cdot 9$

$13 \cdot 5$

5.1 transfer payments

caseload, 1973-1979

60.3

10.8

$4 \cdot 5$

$10 \cdot 9$

9.2

$3 \cdot 9$

STATE TOTALS MAY NOT ADD TO ONE HUNDRED PERCENT DUE TO INDEPENDENT ROUNDING ERROR 
Cioals

Cities and towns do not establish goals inderendent1y. HUD requires that they be responsive to expressed needs in the degree of need to be met (five percent for annual or current need; fifteen percent over the three year cycle) and in the relative proportions of household types ( elderly and handica $\frac{1}{2} p p e d$, small. fami.ly, large family) to be assisted. Since the goals are to sixch a large extent prescribed through suggestion as well as regulation, the statement of need more than that of goals provides the opportunity for flexibility and latitude on the part of the city or town.

HUD has the authority and responsibility to monitor not only the plans but also performance. The Department may require action to remediate disproportional performance as has been done in Warwick.

TABLE III shows the relative share of goals expressed in most recent HAPs as well as the number of units proposed in annual and three year goals. 


\section{TABLE IIIa}

HAP Goals for Deep Subsidy Assistance METROPOLITAN CORE MARKET AREA

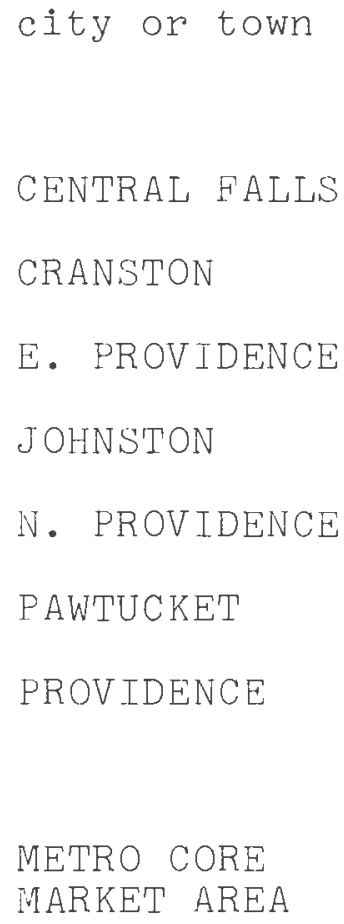

units $\%$ of state total

293

125

130

278

215

310

381

1732
$9 \cdot 7$

4.1

$4 \cdot 3$

9.2

7.1

10.2

12.6

57.2 three year goals

$\begin{array}{ll}\text { units } & \% \text { of state total } \\ 350 & 5.6 \\ 340 & 5.4 \\ 190 & 3.0 \\ \mathrm{n} / \mathrm{a} & \mathrm{n} / \mathrm{a} \\ 263 & 4.2 \\ 720 & 11.5 \\ 1220 & 19.5 \\ & \\ 3083 & 49.4\end{array}$

3093

49.4 


\section{TABLE IIIb}

HAP Goals for Deep Subsidy Assistance NORTHERN R.I. MARKET AREA

city or town

CUMBERLAND

LINCOLN

N. SMITHFIELD

SMITHF IELD

WOONSOCKET

NORTHERN R.I. MARKET AREA annual goals

units

$\%$ of state total

51

20

$\mathrm{n} / \mathrm{a}$

33

130

1.7

.7

$\mathrm{n} / \mathrm{a}$

1.1

$4 \cdot 3$

234 three year goals

units

$\%$ of state total

265

4.2

128

2.0

$n / a$

$n / a$

81

$1 \cdot 3$

245

3.9

719

11.5 
TABLE IIIC

HAP Goals for Deep Subsidy Assistance

WESTERN R.I. MARKET AREA

city or town

BURRILLVILLE

COVENTRY

EXETER

FOSTER

GLOCESTER

SCITUATE

W. GREENWICH

WESTERN R.I. MARKET AREA annual goals

units \% of state total

$n / a$

$n / a$

$3 \cdot 3$

$\cdot 3$

.2

.2

$n / a$

$\mathrm{n} / \mathrm{a}$

10

$\cdot 3$

132

4.4
511

8.2

three year goals

units $\%$ of state total

$n / a \quad n / a$

$320 \quad 5.1$

$20 \quad \cdot 3$

$21 \quad .3$

$45 \quad .7$

$75 \quad 1.2$

$30 \quad .5$ 


\section{TABLE IIId}

HAP Goals for Deep Subsidy Assistance WEST BAY MARKET AREA

\begin{abstract}
city or town
E. GREENWICH

N. KINGSTOWN

WARWICK

W. WARWICK
\end{abstract}

WEST BAY

MARKET AREA annual goals

units \% of state total

$\begin{array}{rr}12 & .4 \\ 60 & 2.0 \\ 125 & 4.1 \\ 144 & 4.8\end{array}$

341

$11 \cdot 3$

939

15.0 
TABLE IIIe

HAP Goals for Deep Subsidy Assistance

EAST BAY MARKET AREA

city or town

BARRINGTON

BRISTOL

JAMESTOWN

LITTLE COMPTON

MIDDLETOWN

INEWPORT

PORTSMOUTH

TIVERTON

WARREN

EAST BAY

MARKET AREA annual goals

units $\quad \%$ of state total

$n / a$

39

30

$\mathrm{n} / \mathrm{a}$

42

18

19

20

19

187

$\mathrm{n} / \mathrm{a}$
1.3
1.0
$\mathrm{n} / \mathrm{a}$
1.4
.6
.6
.7
.6

6.2 three year goals

$\begin{array}{cc}\text { units } & \text { \% of state total } \\ n / a & 1.5 \\ 95 & 1.8 \\ 112 & n / a \\ n / a & 1.3 \\ 84 & 2.5 \\ 157 & .9 \\ 57 & 1.5 \\ 96 & .9 \\ 57 & \end{array}$

658
10.5 
TABLE III

HAP Goals for Deep Subsidy Assistance

SOUTHERN R.I. MARKET' AREA

city or town

CHARLESTOWN

HOF K INTON

INARRAGANSETT

INEW SHOREHAM

RICHMOND

S. KINGSTOWN

WESTERLY

SOUTHERIV R.I. MARKET AREA annual goals

units $\%$ of state total

$\begin{array}{rr}7 & .2 \\ 9 & .3 \\ 41 & 1.4 \\ \mathrm{n} / \mathrm{a} & \mathrm{n} / \mathrm{a} \\ 11 & .4 \\ 116 & 3.8 \\ 220 & 7.3\end{array}$

404 three year goals

units $\%$ of state total

$\begin{array}{rr}21 & .3 \\ 27 & .4 \\ 119 & 1.9 \\ \mathrm{n} / \mathrm{a} & \mathrm{n} / \mathrm{a} \\ 33 & .5 \\ 135 & 2.2 \\ \mathrm{n} / \mathrm{a} & \mathrm{n} / \mathrm{a}\end{array}$

3.35

5.4 
TABILE IIIg

HAP Goals for Deep Subsidy Assistance

R.I. MARKET AREAS

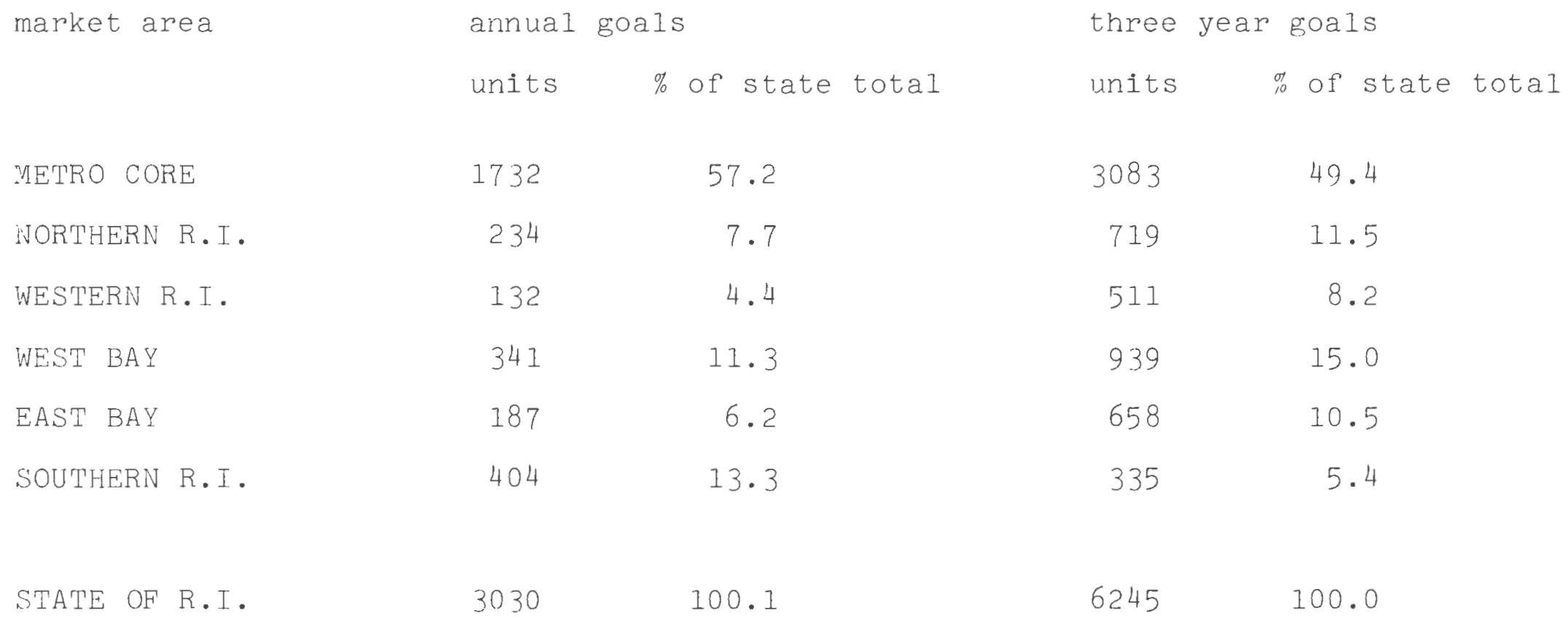


Performance

In the final analysis, it is performance that best demoristrates communities' commitment to the goals of the legislation as well as HUD's ability to monitor, administer and implement those goals.

Some confusion and consequent opportunity for tabulating error occurs due to the tifferences in fiscal year form July first in most municipalities to October first for Fedeeral agencies. Further, the HAP is intended in most cases to apply to the program year following that of the overall CDBG application of which it is a part. Communities are expected to revise needs and goals according performance (housing assistance provided or having a "firm financial commitment"; the definition of this term varies by program.)

Only very recently has HUD begun any thorough analysis of performance with respect to HAP needs and goals. Even now there exists no aggregated data from HAPs at either the Providence or Boston offices. HAP evaluation apparent Iy continues to be carried out on the basis of one at a time, outside the context of previous HAPs, of performance in terms of housing provided, and without relationship to 
to market areas or any other inter-community considerations

As was implied in the political and legislative history of fousing and Community Development Acts and actions of recent years, there was considerable pressure upor HUD to get programs moving following the Nixun moratorium, to get money into local communities quickly. This may account for sorne of the apparent delay in HUD monitoring of performance. Further, the structure of the CDBG/HAP process provides for a three year cycle during which housing and CD funds might flow in variable amounts and rates. It is therefore somenhat understandable that no major evaluation has occurred to date. It is nevertheless regrettable that some of the disparities and inequities in performance have been permitted to go on unimpeded for so long. This year, HUD has threatened or carried out limited sanctions or pressure tactics to correct communities with disproportional or otherwise inadequate performance.

Table IV displays data concerning units constructed under the Section 8 Program. This provides a ready measure of performance with respect to needs and goals. Coals have been adjusted to account for some statistics not available of applicable in Table III. 


\section{TABLE IVa}

HAP Needs, Goals and Assistance Provided, 1975-1979 (\% of state total)

METROPOLITAN CORE MARKET AREA

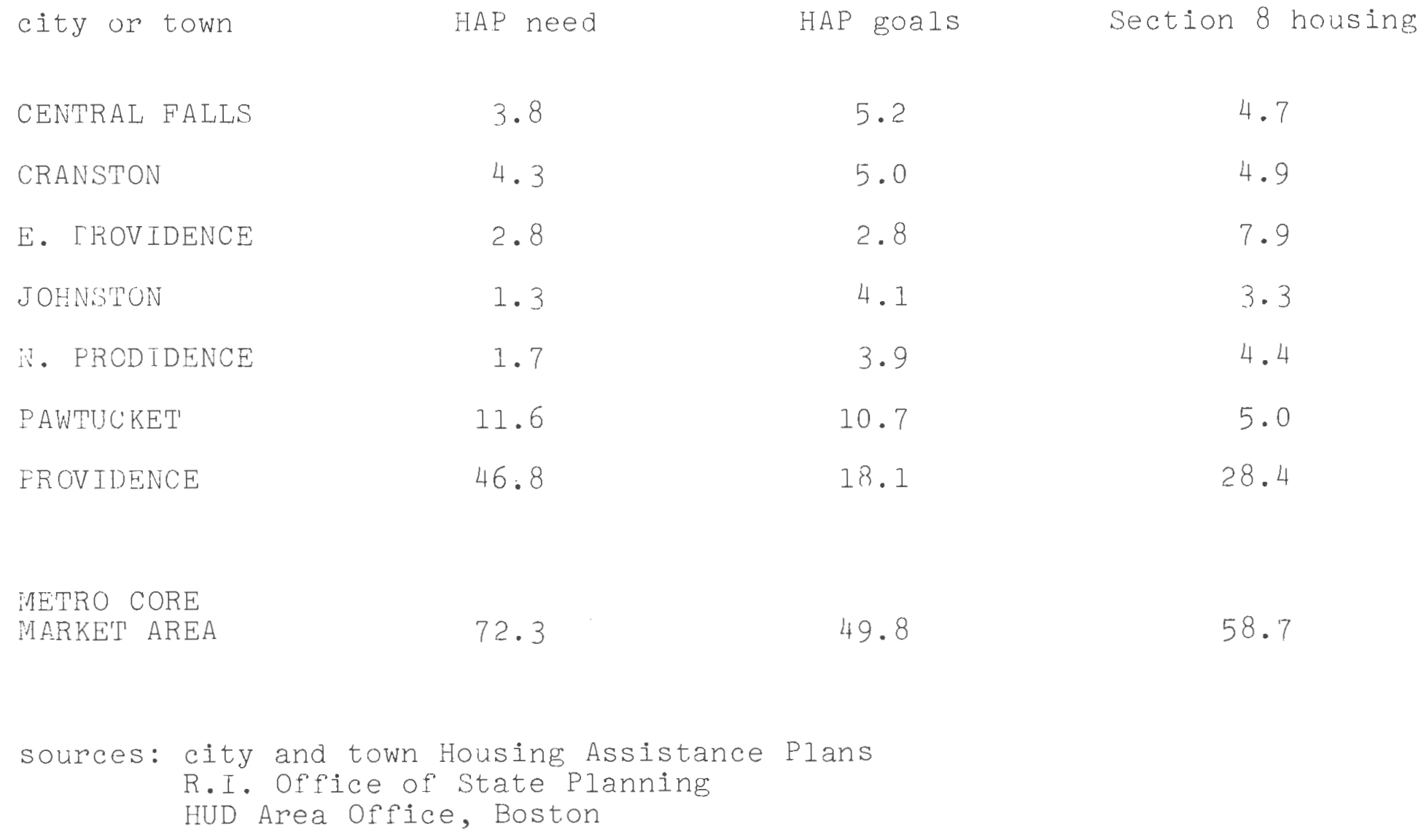


TABLE IVb

HAP Needs, Goals and Assistance Provided, 1975-1979 (\% of' state total)

NORTHERN R.I. MARKET AREA

eity or town

CUMBERLAND

LINCOLN

N. SMITHFIELD

SMITHFTELD

WOONSOCKET

NORTHERN R.I.

MARKET AREA
HAP need

$$
3
$$

$1 \cdot 3$

$\mathrm{n} / \mathrm{a}$

.4

3.8

5.8
HAP goal

$3 \cdot 9$

1.9

$n / a$

1.2

3.6

10.6
Section 8 Housing

3.8

.4

.7

1.8

4.8

11.5 
HAP Needs, Goals and Assistance Provided, 1975-1979 (\% of state total) WESTERN R.I. MARKET AREA

$\begin{array}{lccc}\text { city or town } & \text { HAP need } & \text { HAP goal } & \text { Section } 8 \text { Housing } \\ \text { BURRILLVILLE } & \mathrm{n} / \mathrm{a} & \mathrm{n} / \mathrm{a} & \cdot 3 \\ \text { COVENTRY } & .7 & 4.7 & .7 \\ \text { EXETER } & .3 & .3 & \text { less than } .1 \\ \text { FOSTER } & .3 & .3 & 0 \\ \text { GLOCESTER } & .5 & .7 & \text { less than } .1 \\ \text { SCITUATE } & .1 & 1.1 & .1 \\ \text { W. GREENWICH } & .2 & .4 & \text { less than } .1 \\ & & & 1.2 \\ \text { WESTERN R.I. } & 2.1 & 7.6 & \\ \text { MARKET AREA } & & \end{array}$


HAP Needs, Goals, and Assistance Provided, 1975-1979 (\% of state total)

WEST BAY MARKET AREA

$\begin{array}{lccc}\text { city or town } & \text { HAP need } & \text { HAP goal } & \text { Section } \\ & & & \\ \text { E. GREENWICH } & .4 & .2 & 2.1 \\ \text { N. KIIGSTOWN } & 1.2 & 4.4 & 4.0 \\ \text { WARWICK } & 4.2 & 4.5 & 9 \\ \text { W. WARWICK } & 2.0 & 4.9 & 3.9\end{array}$

WEST BAY

MARKET AREA

7.8

14.1

19.1 
TABLE IVe

HAP Needs, Goals and Assistance Provided, 1975-1979 (\% of state total)

EAST BAY MARKET AREA

$\begin{array}{lccc}\text { city or town } & \text { HAP need } & \text { HAP goal } & \text { Section } 8 \text { Housing } \\ \text { BARRINGTOII } & .4 & 0 & .1 \\ \text { BRISTOL } & 1.2 & 1.4 & .8 \\ \text { JAMESTOWN } & .2 & 1.7 & 0 \\ \text { LITILIT COMPTON } & \mathrm{n} / \mathrm{a} & \mathrm{n} / \mathrm{a} & 0 \\ \text { MIDDLETOWN } & 1.5 & 1.2 & .4 \\ \text { NEWPORT } & 2.0 & 2.3 & 1.7 \\ \text { PORTSINOUTH } & .9 & .8 & .3 \\ \text { TIVERTON } & .5 & 1.4 & .2 \\ \text { WARREN } & .8 & .8 & .8 \\ \text { EAST BAY } & & & 4.5 \\ \text { MARKET AREA } & 7.5 & 9.7 & \end{array}$


TABLE IVf

HAP Needs. Goals and Assistance Provided, 1975-1979 (\% of state total)

SOUTHERN R.I. MARKET AREA

$\begin{array}{lccc}\text { City or town } & \text { HAP need } & \text { HAP goal } & \text { Section } 8 \text { Housing } \\ \text { CHARIESTOWN } & .2 & .3 & .1 \\ \text { HOPKINTON } & .5 & .4 & .1 \\ \text { NARRAGANSETT } & .4 & 1.8 & 1.7 \\ \text { NEW SHOREHAM } & .1 & 0 & 0 \\ \text { RICHMOND } & .4 & .5 & .1 \\ \text { S. KNIGSTOWN } & 1.6 & 2.0 & 2.4 \\ \text { WESTERLY } & 1.5 & 3.3 & .8 \\ & & & 5.2 \\ \text { SOUTHERN R.I. } & 4.7 & 8.2 & \\ \text { MARKET AREA } & & \end{array}$


HAP Needs, Coals and Assistance Provided, 1975-1979 (\% of state total)

R.I. MARKET AREAS

$\begin{array}{lccc}\text { market area } & \text { HAP need } & \text { HAP goal } & \text { Section } 8 \text { Housing } \\ \text { METRO CORE } & 72.3 & 49.8 & 58.7 \\ \text { NORTHERIN R.I. } & 5.8 & 10.6 & 11.5 \\ \text { WESTERN R.I. } & 2.1 & 7.6 & 1.2 \\ \text { WEST BAY } & 7.8 & 14.1 & 19.1 \\ \text { EAST BAY } & 7.5 & 9.7 & 4.5 \\ \text { SOUTHERN R.I. } & 4.7 & 8.2 & 5.2\end{array}$

STATE TOTALS MAY NOT ADD TO ONE HUNDRED PERCENT DUE TO INDEPENDENT ROUNDING ERROR 
Summary and Tnterpretation of Data

The validity of data from HAPs is subject to question as methods used in their preparation are not uniform and, therefore, not truly comparable for purposes of aggregation. Philosophically, however, the HAP can be interpreted to provide at least some, however subjective, expression of community will and intent. I'his is true even if the effort and sophistication brought to bear in preparation varies. It leaves the real intent and commitment of cities and towns suject to conjecture, but does present some circumstantial evidence.

The methodology in the study is likewise less than ideal. Considerable elaboration is possible with respect to additional standardized measures of need, accounting for changes over time, and the correlation of variables. Nevertheless, it is felt that issues have been raised and patterns detected which warrant attention.

I. HUD and its regulations permit substantial overstatement and understatement of need relative to standarized measures which may be applied across municipal boundaries. This allows aggressive housing and communty development agencies to attract housing and less ambitious city and town of $f^{\prime}$ cials to perpetuate racial and economic exclusion, both with the apparent if not intended endorse- 
ent by HUD through approval of the HAPs and through continued CD funding.

II. Goals are to a large extent prescribed in relation to needs. Uncritical acceptance of statements of need, however, results in more or less ambitious goals than can be justified by local self-determination but also equal housing opportunity as simultaneous objectives.

IT. Neither needs nor goals as expressed, even if' they were true to the objectives, seem to bear direct relationship to performance in terms of units provided. However, techniacally correct the HAP may or may not be, political and administrative realities obviously account for some communities' receint of construction and subsidy funding out of proportion to their stated needs and goals. Whether this is again due to more or less initiative on the part of cities and towns, or due to haphazard implementation by HUD, is not entirely demonstrable. It is worthy of correction and within the possibilities for remediation.

Some communities have a record of increased willingness and initiative to pursue funding sources and housing opportunities. This has resulted in more housing in place. This does not mean, however, that an advantageous 
political climate necessarily improves the process. In fact, these factors may have actually made disparities and inequities greater.

What began as an effort to analyze the plans and methodologies employed ard results achieved (presumed to have some connection) has become a demonstration that needs and goals as articulated in HAPs have little if any relationship to what happens on the ground. There is a strong sense that virtually none of the actors really take the plan or its preparation seriously- not the city or town officials or preparing employees, not the state agencies that review or prepare plans, and not HUL which both review and accepts the plans and dispenses funds with which to implement them. 
CHAPTER IV 
CFAPTER FOUR

The legislative and political history of Housing and Community Development, of course, continues.

Dissatisfaction with categorical grants programs had been widespread and suggestions for improvement had originated on several levels. It was largely the U.S. House of Representatives that developed the present method of linking separate housing and community development programs. The House has been the predominant voice in public housing matters over the years. Its Subcommittee on Housing and Community Development appears to exert greater influence in the field than any other single agency. However, both the Subcommittee and the House of which it is a part are subject to a rather uncontrollable and frequently unpredictable forcethe will of the people. Due to the frequency with which members must return to their districts for support, they 
remain very sensitive to the concerns of their constituents.

This aspect of political reality has apparently worked its way into the Housing Assistance Plan and process. It endangers the Federal housing policy that took four years to develop. The HAP was instituted during what proved to be tumultuous times for the $\mathrm{Na}$ tion, its officials and its numerous and varied agencies. It it received a low priority among the concerns of these groups, it might be explained by a general state of confusion and overall lack of direction.

The first two years of the $\mathrm{CDBC} / \mathrm{Hap}$ process proved to be rather unproductive in the national effort to accurately assess the housing needs of low and moderate income groups and to provide housing units for them. The decision rendered in the City of Hartford vs. Hills case brought some of HUD's shortcomings to light and forced the department to respond with new resolve. In addition, the 1976 Presidential election had resulted in a defeat for the Republican administration and in 1977, the nation received a new chief executive and a new Secretary of the Dapartment of Housing and Urban Development. 
Time and circumstance led to a rew era for the Housing and Community Development programs and their component parts. The requirement to produce an accurate HAP became increasingly important, but increased attention paid to the HAP and the accompanying program changes were as unwelcome among some state and local officials as had the original lack of attention. Numerous complaints arose concerning the municipal governments' difficulties in reconciling the programs' promise of maximum flexibility on the local level with the sometimes conflicting requirement to align community objectives with those established nationally.

A number of officials representing local and atate governments continued to voice their concern about HUD's administration of the CDBG program and Congress had become more receptive and responsive to the level of resentment which existed and in many cases persists. Several House members began to feel that HUD Secretary Patricia Harris and Assistant Secretary for Community Planning and Development Robert Embry overstepped their authority and were acting to further reduce what control remained at the municipal level to assess and provide housing facilities. 
This attitude led Michigan Representative Gary Brown to suggest an amendment which would give Congress the power of a one-house veto on any proposal made by HUD to change existing regulations or procedures. Although the amendment was not accepted, it was seen as a warning to HUD that it had to more carefully consider its course of direction. The towse and senate conference Committee did require that HUD submit rules and regulations under consideration to the Houst and senate Banking Committees or a semi-annual basis. In an additional show of force, the Committee dealing with the HUD Appropriations Bill eliminated 115 Area Office positions which had been sought in order to strengthen the department's ability to monitor the CDBG programs at the local level.

It is difficult to draw a great variety of conclusions from the chain of events which form the history of the HAP and it is more difficult still to speculate on the future without calling into question the entire mechanism which is entrusted the responsibility and the power to provide decent homes in suitable living environments. It appears as though the process - ten years and some twenty odd billion dollars along - has come full circle, returned to the point at which it begar. 
It was born in an era of uncertainty over diverse and emotional issues and it remains susceptible to the confusion which automatically results whenever an attempt is made to divide limited resources among numerous and divergent goals. The confusion in which it is now enmeshed is different from that of the early years, but. it continues nonetheless to restrict its ability to succeed in its stated purposes.

In theory, the HAP requires municipalities toacourately assess the housing needs of low and moderate income people and to provide them with suitable housing in those areas where their access has traditionally been denied. In adition, it seeks to assist in the upward mobility of these groups by locating them in areas where they are likely to find employment and the public facilities and services which have come to be considered essential elements in the provision of a decent and suitable living environment. Yet state and local governments across the nation have consistently overlooked the opportunity to assist these groups even when the Federal Government has offered to underwrite the cost. The underlying intention apparently continues despite the obvious message that all parties must share in the responsibility if we are ever to achieve what are hoped to be common objectives. 
The Federal Government therefore frequently operates in an atmosphere of conflict and tension and is forced to elicit support in the form of specific requirements such as the HAP in return for the funds which it. makes available. Yet the objectives which these requirements help to achieve can be undermined by Federal representatives who temporarily or otherwise lose their ability to differentiate between long term objectives and short term objections. It is extremely difficult to serve both a local and a national constituency but it must, be done.

Policy and Politics

If it is possible at all in our political system to arrive at policy consensus and to proceed toward legislative implementation is subject to question. Concurrent if not conflicting objectives compound the problems of structure.

We simultaneously seek national commitment to decent housing with local self-determination. In Rhode Island and probably elsewhere, local cababilities for self expression and local commitment to national goals is variable to a substantial degree. 
We seek governmental involvement and administration in housing, but also the private investment of capital. This requires incentives, namely profits, to developers, builders and mangers which are generated from taxes everyone mist pay. Further, taxes are paid both direcly and indirectly for subsidized housing; federal, state, and local taxes are all involved and usually in unknown quantity. Private profits are generated, also most frequently in ways and amounts unknown to the public and many decision makers.

With multiple goals and multiple beneficiaries, direct, and indirect, it becomes most difficult to arrive at consensus about either ends or means. The hidden agendas are likely to outnumber facts and figures on paper in legislation and planning documents.

Administration

HUD is both a planning and a programming agency . That is, divisions within the Department are variously responsible for providing technical assistance, for the review and judgement of plans and for the dispensing of funds. There exists a fundamental problem of balancing these separate functions. One part of the Department. 
may be advising local communities about how to apply for funds from another. This means that both the advisor and funding agent can exert considerable influence on the form and content of applications which are supposedly self-determinations. Simultaneously, HUD is charged with administering acts which have provision for both federal and local control of some ends and some means.

In a sense, we are left. with the worst of both worlds. The "strings" resented under categorical grant programs remain, but so does the "flexibility" and potential for inequities of block grant programs with local control.

The HAP itself and the manner in which it is used has schizophrenic qualities. It is used as an expression of local wants and needs, influenced by HllD requirements that it be "reasonable" with respect to anticipated funding modes and levels, and also used to justify HUD appropriation requests to Congress. A town that asks for what it. wants is told by HID to request, what it can expect to get; HUD then asks Congress for what the community was told to request. Who can possibly know what. the document means within this circuitous maze of mearing? 
Maybe it is just as well that no one seems to take the document seriously.

Planning - an answer?

Major national policies seem to emerse at least once per decade, but are subject to incremental modification almost every year. If the nation is tver to achieve objectives established in high sounding phrases like "a decent home...for every American family" it must make substantial effort to arrive at consersus, to develop policy, polities and administration that further the goals selected. This may best be accomplished through the development of policy relevant knowledge. Information must be developed on the local state, regional and national levels and funds made available for. housing information systems capable ol storing, retrieving and analyzing data.

HUD, for example, currently collects a great deal of information, but not only isn't it generally distributed, but its own of'ices lack accessible data such as aggregations of HAP entries. In the bureaucracy, too often "someone" has or must have the information, but either no one knows or will reveal who "someone" is. 
Iocal communities share a variety of problems, but seem to address them independently and individually. There seems no opportunity or vehicle for information exchange and mutual assistance in problem solving or planning.

At the risk of further complicating the already complex practical and administrative difficulties in the programs and process to date, the major recommendation of this study centers on the potential role of state government.

Rhode Island communities continue to produce HAPs of questionable validity, value or impact. The record of the state as a whole is one of having taken advantage of most federal funds and programs available. If there is any statewide housing policy or approach, it seems to be the caoture of all the foderal fiunds possible, but with less attention to the in-state dispersion and distribution of those funds.

This relative policy vacuum with respect to state government may be the very feature that makes it feasible to exercise political leadership at this point. Having avoided some of the conflicts between HUD and the locals 
may prove to be an davantage, an opportunity for the State to bridge the gap between federal and local goals and perspectives, to provide policy relevant information and knowlwdge and, most of all, to provide leadership and direction where little if any exists at other levels of government.

We recognize that there are problems with superimposing state influence in areas where there is already substantial complexity, confusion and conflict.

Concepts such as state and regional housing allocation plans and Areawide Housing Opportunity Planning have been attempted with mixed reaction and success. One problem with these approaches is in the area of incentives. Redistribution of allocations and planning funds are not enough to make these mechanisms useful. In Rhode Island, there has already been expressed the attitude that if nobody wins, nobody loses. That is, many are satisfied with the status quo with its disparities; even those not satisfied might prefer it to an unknown future sta1.e.

If planning is to become more than whatever the f'ederal government has funds for, the catalyst must be 
found that makes plans happen. That catalyst is political leadership. It is hoped that this project is more than an idealistic student project with planning, and more of it, as the panacaea. It is an appeal for action at the level of the Governor and state and federal legislators as well as local government. We seek, indeed demand a polities which is not only the art of the possible, but one which seeks and does what is right. 
BIBLIOGRAPHY 
BOOKS, GOVERNMENT PUBLICATIONS, AND REPORTS

Aaron, Henry J. Shelter and Subsidies: Who Benefits from Federal Housing Policies? Washington: The Brookings Institution, $19 \overline{9} \overline{2}$.

Birch, David et al. America's Housing Needs:19701980. Cambridge: Joint Center for Irrban Studies Harvard/MIT, 1973.

Citizens Housing and Planning Association. Community Development Block Grants and Neighborhood Re-vittalization: A Handbook. Boston: August, $197 \overline{8}$.

Franklin, Herbert $M$. and Levin, Arthur J. The Housing Assistance Plan: A Non-Working Program for Communtey Tmprovent ? Institute, November, 1975.

Frieden, Bernard J. and Solomon, Arthur P. The Nation's Housing: 1975-1985. Cambridge: The Joint Center, $\overline{1} \overline{7} \overline{7}$.

Hartman, Chester w. Housing and Social Policy. Englewood Cliffs, N.J.: Prentice-Hāil, $1 \overline{9} 75$.

Massachusetts, Commonwealth of. Executive Office of Communities and Development. Housing Massachusetts: The Housing Element for the Commonwealth. Boston: Aprìi, 1978.

- Housing Needs in Massachusetts.Boston: Sept., 1978

- Housing Policy Statement for Massachusetts. Boston: November, 1975.

Metropolitan Area Planning Council. Areawide Housing Opportunity Plan. Volumes I, I . Boston: September, 1979.

- Impacts of Housing Development on Community and Region. Boston: September, $197 \overline{7}$

- Resources for Community Development, Neighborhood Revitalization and Housing Rehabilitation. Boston: Ju1y, $19 \overline{7} \overline{8}$.

Mucha, Frank A. Techniques in FHA Housing Market. Analysis. Washington: $\bar{F} \bar{H} \bar{A}, \overline{1} \bar{g} 66$. 
National Association of Housing and Redevelopment Officials. On Iow to Prepare a Local Housing

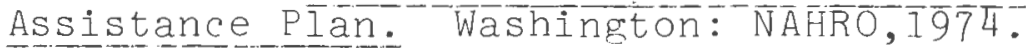

The National League of Cities. A Guide to the Housing and Community Development Act of 1977. Washington: october, $197 \overline{7}$.

National Model Cities Community Development Directors Association. A Guide to Preparing Housing Assistance Plans. Washington: December, 1974.

Pynoos, John, ed. Housing Urban America. Chicago: Aldine Publishing, $\overline{1} \overline{9} \overline{3}$.

Real Estate Research Corporation. The Costs of Sprawl. Washington: GPO, 1974.

- Program Potentials in Housing: A Regional Action Program. Washington: NERC, 1970

Rhode Island Department of Community Affairs. Annual State Report on Local Government Finances and Tax Equalization. Provideñe: annuàiy.

- Black Families in Rhode Island. Providence: July, 1975 .

- Definition of Housing Market Areas for Rhode Is land. Providence: November, $\overline{1} \overline{9} \overline{2}$

- Federally Assisted Multi-Family Housing in Rhode Is land. Providence: October, 1976 ; January, 1978 .

- Housing Need for Low and Moderate Income Families in Rhode ls iand. Providence: $19 \overline{7} \overline{3}$

- Housing Planning in Rhode Is land: Guidelines and Recommendations. Providence undated.

- Low Rent Public Housing In Rhode Island. Providence: December, $197 \overline{2} ;$ December, 1976. - A Review and Analysis of Housing Difficulties for Large Families in Selected Areas of R.

Providence: 1972 .

- The Role of State Government in the Housing Market. an address by Lt. Governor J.J.rarrahy, May $\overline{1} \overline{7}, 1972$ issued as Housing Memo 72-9. 
Rhode Island Department of' Community Affairs.

Selected Housing, Population and Property Tax

Data. Providence: 1972 .

.... Selected Housing Stock Information in R. I. Providence: $1975 ; 1978$.

Rhode Island Department of Economic Development. R.I. Basi Economic Statistics: The Economy, Summary and Trends. $19 \overline{9} \overline{9}-\overline{1} \overline{80}$.

- Rhode Islan Fact_Book. 1978.

Rhode Island Department of Social and Rehabilitative Services. Statistics on Assistance Payments Caseloads and payments. Cranston: monthiy.

Rhode Island Governor. Message to the General Assembly Providence: annual1 $\bar{y}, 197 \overline{3}-1979$.

- Policy 176. Providence: November, 1976.

Rhode Island Statewide Planning Program. Rhode S land Population Projections by County, City and riown. Technical Paper $\overline{2}$, Providence: $\overline{1} \overline{9} 75$

- Socio-Fconomic Projections for Rhode Island: 1980 and 2000 . Technical Papur 73. Providence: July, $1 \overline{9} 7 \overline{8}$.

- State Land Use Policies and Plan. Report Number 22 . Providence : Janiary, 1975.

- State Planning for Human Services in Rhode Island. Report ivumber 24. Providence: July, 1975.

- State Housing Information System: Federally Assisted Rental Housing. Providence: Tuly, 1979. - State Housing Plan. Providence:July, 1978. - Strategy Rhode Island: A Campaign to Target and Anchor Tndustria opportunity in $\bar{R}$. $\overline{\mathrm{N} u \mathrm{mb}} \overline{\mathrm{r}} \mathrm{3} \mathrm{\sigma}_{\mathrm{A}}$. Providence: $19 \overline{9} \overline{9}$.

Solomon, Arthur P. Housing the Urban Poor: A Critical Evaluation of Federal Housing Policy. Cambrige: The Joint Center for Urban Studies, Harvard/MJT, 1974 . 
United States Bureau of the Censis. various reports.

U.S. Congress. Congressional Budget Office.

Federal Housing Policy: Current Programs

and Recurring Is sues. Washington: Govérnment Printing office, June, 1978.

- Congressional Research Service. The Housing and Community Development. Act of 1974 : Summary and Anàysis. Washington: 1975 .

- Analysis of Selected Housing Programs.

Washington: $\overline{1} \overline{7} \overline{8}$

- General Accounting Office. Domestic Housing. and Communtiy Development, Issues for Planning. Washington: $\frac{\mathrm{J}}{\mathrm{u}} \overline{\mathrm{y}}, \overline{\mathrm{l}} \overline{\mathrm{g}} \overline{\mathrm{T}}$.

U.S. Department of Housing and Urban Development. City Need and Community Development Funding. Washington: HUD, January, 1979.

- Comprehensive Land Use Planning: Back to Basics. Washington: HUD, $197 \overline{7}$.

- Comprehensive Planning Assistance:701. Washington: HUD, August, $19 \overline{7}$.

- Developing a Local Housing Strategy. Washington: $\overline{\mathrm{G}} \overline{\mathrm{P}} \mathrm{O}$. November, $1 \overline{9} 7 \overline{8}$.

- "Instructions for Boston Area Office Appiicants." Boston: HUD, 1980.

- "Instructions for forms HUD-7091 through HUD- 7095." Washington: 1979.

- "Instructions for Small Cities Comprehensive Grant Applications." Washington: 1978.

- "Instructions for Small Cities Single Purpose Program." Washington: 1980.

"Inventory of Federally-Assisted Multi-Family Rental Housing Developments." computer printout dated 1 July, 1979.

- Local Housing Assistance Tools and Techniques. Washington: GPO, November, 1978 . 
U.S. Department of Housing and Urban Development. The Private Development Process: A Guidebook for Local Government. Washington: G $\bar{P} O, \overline{1979}$.

- Programs of HUD. Washington: GPO, May, 1978.

- The Frovidence Housing Authority: A Comprehensive Coordinated Marnagement Review. Providence service Office: February, $19 \overline{8} \overline{0}$.

- The Role of the Real Estate Sector in Neighborhood Change. Washington: GPO, March 1979.

U.S. House of Representatives. Committee on Banking, Finance and Urban Affairs. Housing and Community Development Legiglation - $19 \overline{7} \overline{3}$. Parts $\overline{\mathrm{I}} \overline{\mathrm{I}} \overline{\mathrm{I}}, \overline{\mathrm{I}} \overline{\mathrm{I}}$. Washingtion: ḠP

- The Housing and Community Deve1opment Act of 1974 .

- The Housing and Community Development Act ot 1977 .

- Housing and Community Deve1opment Amendments, 1978 .

- Basic Laws and Authorities on Housing and Community De relopment. Parts I, I revised through January $\overline{3}, \overline{1} \overline{7} \overline{8}$.

-_- $\cdot$ Community Development Block Grant Program: $\bar{A}$ Staff Report. February $\overline{8}, \overline{1} \overline{7} \overline{7}$. 
PERIOD ICALS

HUD Challenge - the official publication of the U.S. Department of Housing and Urben Development

Beale, John. "Community Development Block Grants: What Impact So Far?" Vol. VI, No. 4, May, 1975.

Espenshade, Regina and Walther, Joyce. "Planning, for Housing" Vol. VI, No. 10. October, 1975.

Read, Jennifer McMurray. "Summary of HUD Activities One Year After the Housing and Community Development Act of 1974." Vol. VI, No. 12. Dec. 1975.

Hills, Carla. "Fair Housing is Everybody's Business." Vol. VII, No. 4. April, 1976.

The Journal of Housing - the official publication of The National Association of Housing and Redevelopment Officials

Nenno, Mary K. "Administration and Congress Chart Divergent Courses for Future Federal Housing Assistance." Vol. 30, No. 9. October, 1973.

NAHRO Board of Governors. "NAHRO Calls for Immediate Responsible Action." Vol. 31, No.4. April, 1974.

_._. "The State of Affairs in Housing and Community Development." Vol. 32, No. 8. August, 1975. - "NAHRO Reports on its Monitoring of the First Year of the CD Program." Vol.32, No.9. Oct.1975.

McFal1, Truay. "Housing Allocation Plans." Vol.35, No. 2. February, 1978.

Nenno, Mary K. "The 10-Year Housing Goals" Vol.35, No. 7. July, 1978.

Perleman, Konrad "New CD Regulations Make Planning Vital." Vol. 37, No. 1. January, 1980. 